\title{
Genuine Prestige Goods in Mortuary Contexts: Emulation in Polychrome Silk and Byzantine Solidi from Northern China
}

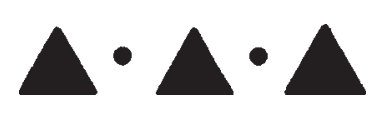

Armin SelBitschKa

\begin{abstract}
Archaeologists across all fields of research usually conflate prestige and social status with their use of the concepts "prestige" and "prestige goods." As a consequence, discussions of prestige goods focus on their active use in status competitions. Prestige is not equal to but one of several contributing factors to social status, however. Prestige is akin to the German noun ansehen, which expresses the notion of looking up to someone because of certain qualities possessed by that individual. This has serious ramifications for the traditional understanding of prestige goods. In order to distinguish genuine prestige goods from non-prestige goods in mortuary data, it is necessary to look beyond the motives of individual signalers and instead concentrate on the reactions of responders. Examining emulation of prestigious individuals unlocks the views of contemporary responders in ancient times. Copies of objects yielded from burials are tangible manifestations of ansehen (prestige). They convey the information that certain sets of individuals viewed the original items as more than mere luxury products or status symbols. To be sure, genuine prestige goods are most likely of high relative value, but they operate on a deeper social level than luxury items and status symbols. Genuine prestige goods highlight certain aspects of the attitudes of smaller pockets of society rather than universal social mechanisms. An in-depth analysis of various silk fabrics and emulated warp-faced compound tabby weaves (jin 錦) dated from the second to early fifth century C.E. burials in the Tarim Basin in the Xinjiang Uighur Autonomous Region, PR China, along with a brief survey of Byzantine solidi (gold coins minted by the Eastern Roman empire) and their copies found in early sixth to mid-eighth century C.E. tombs in northern China, serve as the material basis for the argument about emulation and ansehen. KeYwords: prestige goods, emulation, Silk Road, Xinjiang archaeology.
\end{abstract}

\section{INTRODUCTION}

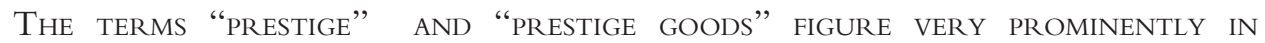
ARCHAEOLOGICAL STUDIES that seek to reconstruct past social orders. More often than not, status is used synonymously with prestige and, as a consequence, status symbols and prestige goods are treated without any degree of differentiation. The production

Armin Selbitschka is a Professor (Chair) of Ancient Chinese History and Archaeology at Ludwig Maximilians University (LMU) Munich. 
and exchange of prestige goods are generally held to mark the beginning of social inequality and thus the start of complex society. Certain individuals actively used prestige goods to exert power over people who were not in possession of such objects.

However popular such notions of prestige and prestige goods may be among archaeologists, remarkably, neither sociological nor archaeological theorists have provided distinct definitions of either concept. It is no less surprising that, although both concepts are widely applied in studies of the early Silk Roads, scholars have failed to reflect on their deeper significance. Many books and articles refer to prestige goods without explaining what the notion actually means (e.g., Bunker 2001:22, 36; Liu 2010:4; Sheng 2013:178, 181). So far, common explanations of prestige goods among archaeologists have been too vague on the one hand and too narrowly focused on their function as tools of political and economic power on the other. Artifacts that have been identified as prestige goods were rarely more than status symbols. They reflected the exact positions their owners held in hierarchically structured societies, but these did not necessarily generate prestige, as may have been intended by the owner. In a stricter sense, prestige is not inextricably linked to the status of an individual. Many different interpretations notwithstanding, scholars usually assume that prestige is akin to esteem. A brief contemplation of the essential meaning of esteem as a social force already suggests that prestige is a relative concept that can only be ascribed by someone other than the self.

Naturally, this causes serious problems for archaeologists, because archaeologists rely on mortuary data more heavily than other sources when assessing matters of social structure, despite the many limitations of these remains. Mortuary data barely enable us to catch a somewhat objective glimpse of the social attitudes held by the deceased and their immediate families, let alone the views of third parties. Nonetheless, I propose that identifying instances of emulation in the mortuary record allows us to determine which artifacts generated real prestige. Analyses of silk textiles from several second to early fifth century C.E. cemeteries on the southern rim of the Tarim Basin (roughly at the center of the Xinjiang Uighur Autonomous Region, PR China) and a survey of Byzantine solidi from various graveyards in northern China suggest that it is crucial to look beyond the motives of signalers or signaling groups if one seeks to recognize genuine prestige goods in archaeological contexts (Fig. 1).

Some of the inherent qualities of both kinds of finds apparently appealed to wider audiences as they were transmitted from China to the Eastern Roman Empire and vice versa. At first, woven fabrics from unspun silk threads were unknown in the Mediterranean world and thus were truly rare, exotic, and costly objects. Similarly, golden Byzantine solidi that weighed roughly $4.5 \mathrm{~g}$ and carried the portrait of a human being were unknown in the early medieval Chinese cultural sphere. Objects made of gold were niche products at the time and Chinese coins exclusively featured Chinese writing rather than anthropomorphic iconography. The archaeological record indicates that Chinese silks and solidi were highly coveted by some people, yet the genuine articles remained unattainable to all but a few. By way of studying copies of these two types of artifacts in their social contexts, I contend that the act of emulation expresses more than a one-dimensional striving for political control or evolutionary advantage (Boyd and Richerson 1985:288). It has the capacity to expose the intricate interplay between social actors on a deeper, more personal level.

In order to methodologically separate the prestige goods that fit my definition from vaguely defined prestige goods mentioned in earlier studies, I call such items "genuine prestige goods." This article starts with a review of the most pertinent arguments on 


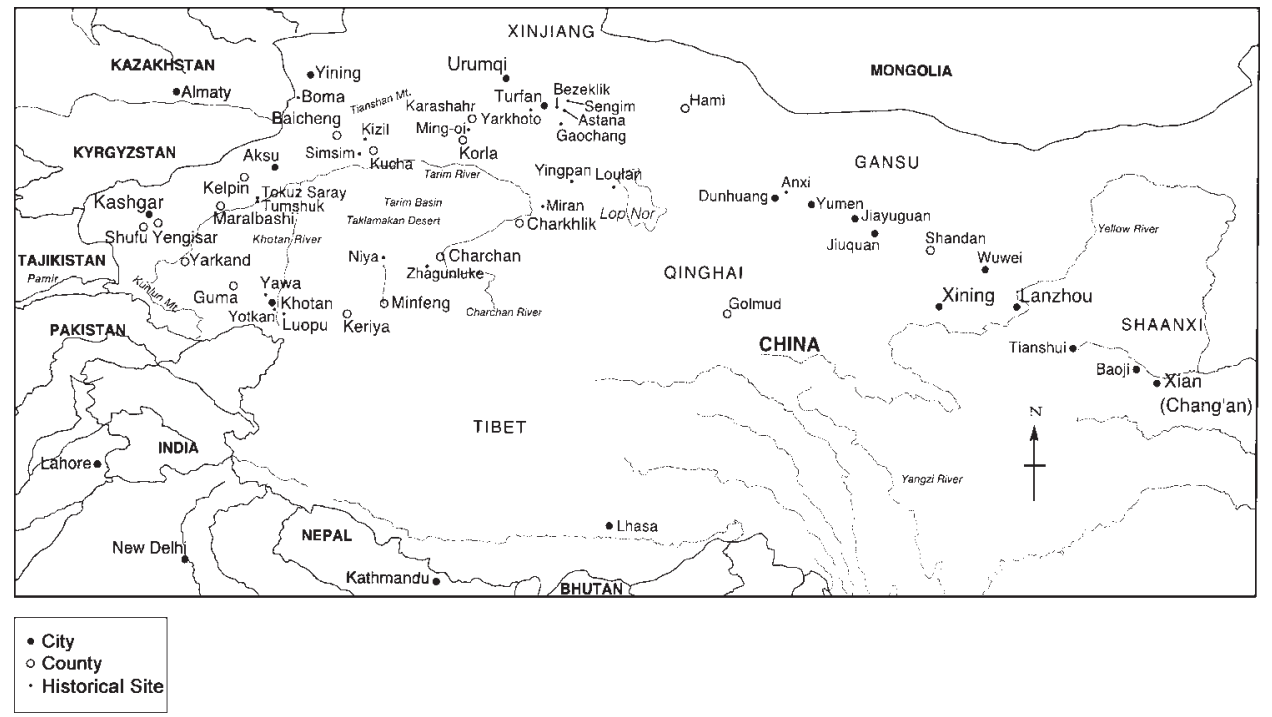

Fig. 1. Archaeological sites in Xinjiang Uighur Autonomous Region, PR China (after Li 2003:14).

prestige goods in archaeological research and then proceeds to an in-depth discussion of notions of status and prestige in sociological literature. I then develop seven criteria for establishing the high relative value of grave goods that will enable scholars to recognize genuine prestige goods in archaeological contexts. In general, the more valuable an item was, the likelier that it generated prestige for its owner. The seven criteria are applied in two case studies of early imperial and early medieval Silk Road finds from northwestern and northern China.

\section{PRESTIGE GOODS IN PREVIOUS SCHOLARSHIP}

In present-day vernacular the term "prestige good" is commonly used to describe costly objects that enhance the status of social actors by demonstrating their economic wealth. Such understanding of prestige goods dates back to 1899 (1934) when Thorstein Veblen published The Theory of the Leisure Class. The book famously introduced the concept of conspicuous consumption, which refers to members of stratified societies spending large amounts of money on things and displaying them ostentatiously. In reaction to such behavior, members of lower social levels often attempt to emulate higher ranking members of society in order to enhance their own social positions.

Marcel Mauss (1923-1924, 1966) picked up on conspicuous consumption while discussing the so-called potlatch practice once customary among Native American tribes of the coastal Pacific Northwest. Here, improving one's social standing did not depend on showcasing wealth, but giving it away or destroying it. The underlying rationale was that expensive gifts required reciprocation (with interest). In cases where the recipient was unable to settle this debt, the giver wielded power over him. For instance, if some chieftains were able to take more highly valued copper plates out of circulation than their competitors, their own status increased (Clark and Blake 1994; Gosden 1987). 
Pierre Bourdieu (1977, 1986, 1989, 1990; Anheier et al. 1995) has refined Veblen and Mauss' notion of conspicuous consumption and expanded on Karl Marx' understanding of economic capital by introducing additional concepts: cultural capital, symbolic capital, and social capital. In principle, social capital describes the sum of social contacts an individual can rely upon. These are mostly generated within groups as social units and maintained by networks of various sizes (Coleman 1988; Durlauf and Fafchamps 2005; Lin 1999, 2001; Ostrom 2000). Cultural capital exists in three forms: embodied cultural capital is mainly based on socialization through family and education; objectified cultural capital denotes the use of certain material objects and the knowledge (based on embodied cultural capital) to use or appreciate them; and institutionalized cultural capital expresses itself, for instance, in academic titles. The interplay of these different forms of capital essentially determines symbolic capital. The way we talk or dress is one of several possible manifestations of symbolic capital; it makes our abilities visible to our social environment and thus is subject to its judgment.

Although Veblen, Mauss, and Bourdieu did not explicitly discuss prestige goods, their main arguments served as the theoretical framework for most subsequent studies, regardless of the respective fields in which they were conducted. For example, Veblen's insights were eagerly applied by economists (Bagwell and Bernheim 1996; Trigg 2001), anthropologists (Bliege Bird and Smith 2005), and archaeologists (Bagley and Schumann 2013; Clark and Blake 1994; Dietler 2011:183; Kristiansen 2012), despite occasional criticism of the original argument (Campbell 1995).

As far as the discussion of prestige goods among archaeologists is concerned, Aimée Plourde $(2006,2008,2009)$ has most recently demonstrated that prestige goods not only originated with the advent of, but were essential for the formation of hierarchically structured societies. Following Amotz Zahavi (1995; Zahavi and Zahavi 1997), she argues that objects can be used to "honestly" transmit certain skills of an individual to an audience (Plourde 2009:268). These skills may include the ability to ensure subsistence by hunting or to establish good relations with people beyond the immediate social milieu (Plourde 2009:268). Plourde (2008:376) contests that prestige goods ultimately are a "manifestation of the end product of their [i.e., the proprietor's] operation," and as such they need to be costly to generate prestige. Based on these assumptions, Plourde has devised a theoretical "costly signaling model" through which prestige goods can be discerned as "honest" symbols of skill (Plourde 2006:4, 26, 46-68, 2008:378-381). Her arguments are essentially rooted in the work of evolutionary anthropologist Robert Boyd and evolutionary biologist Peter J. Richerson. Both scholars asserted on numerous occasions that the majority of the population ("naive individuals"; Boyd and Richerson 1996:80) choose to imitate the actions of cultural leaders because it is less "costly and error prone" (Boyd and Richerson 1996:84) than learning cultural behavior on their own (see also Boyd and Richerson 1985:242-245; Richerson and Boyd 2001:449). This means, in turn, that the vanguards of society would have to invest more time and effort (i.e., costs) than others in order to assume their prominent roles. Intuitively, one would suppose that expending more resources might result in a reproductive disadvantage, but costly signaling theory (CST) aims to show that the opposite is true. As Stephen Shennan asserts, "investing in the gaining of status to the detriment of reproduction can lead to greater fitness in the medium- to long-term" (2002:225, 2008).

Darwinian archaeology is but one strain of archaeology that makes use of the prestige and prestige good concepts. Jonathan Friedman and Michael Rowlands (1977) 
were the first scholars to publish a sophisticated explanation of the prestige good concept. Accordingly, prestige goods serve as luxury and ceremonial items in fledging complex societies. Those who command their production and exchange reinforce their own ritual superiority and exert economic control over the rest of society. For example, domination of the agricultural output can be converted into prestige through elaborate displays of wealth in feasts (Friedman and Rowlands 1977:221-222). Even more influential is the argument that the initial hierarchization of societies was only facilitated by the control of foreign prestige goods. Actors who were skilled enough to establish and sustain long-distance relationships that granted them access to revered materials or objects (i.e., prestige goods) attained higher status and thus exerted economic and political power over the community. Susan Frankenstein and Michael Rowlands (1978) subsequently emphasized this point and it has been widely adopted in many subfields of archaeology ever since (Brumfiel and Earle 1987; Champion 1982; Eggert 1991; Haselgrove 1982; Junker 1993; Kim 1994; Kristiansen 1987; Peregrine 1991b, 1992, 1996; Pirazzoli-t'Serstevens 1992; Shennan 1982a, 1982b; Underhill 2002). Although not quite as popular, stressing the social and political advantages that the control over the production of prestige goods brought to selected individuals has also gained traction among some scholars (Costin 1991; Hayden 1998; Kim 2001; Liu 2003; Peregrine 1991a).

Plourde was therefore but the last in a long list of scholars who share the assumption that the political elites of non-capitalist societies actively employ prestige goods - also described as prestige items, wealth goods, wealth items, luxury goods, exotic goods, or status symbols - in order to maintain their superior positions. This is achieved either by controlling foreign trade and thus restricting access to exotica or by commanding the labor of specialized or attached craftsworkers and consequently the sought-after products they create. In contexts of emergent complexity, the power exercised by political leaders through the use of prestige goods eventually gave way to stratified societies.

Instead of relying on the work of Veblen or Mauss, Colin Renfrew (1986) initially assumed a Marxist approach. To his mind the concept of value was ideally suited to come to terms with the abundance of golden artifacts that emerged from mid-through late fifth millennium B.C.E. burials at Varna, Bulgaria. In a more recent study, Renfrew (2012) elaborates on the subject and concludes that value as a heuristic tool needs to be thoroughly defined before it can be applied to archaeological material. The Varna gold and other metals throughout European and Western Asian antiquity may have been highly valued and thus prestigious in some cultures, but contemporary cultures in other parts of the world may have prescribed to different value systems. In Neolithic China, for example, jade seems to have been favored as a so-called prestige good. Be that as it may, Renfrew's conclusions are ultimately similar to evolutionary and more traditional approaches. He and others contend that during periods of emerging metal production, having command over certain types of metal such as gold or copper greatly enhanced the owner's social status and thus fostered social inequalities (Flad 2012:321-326; Liu 2003:4-17).

A limited number of scholars have been somewhat critical of the established view of prestige goods. For instance, Rowan Flad and Zachary Hruby (2007:9) oppose the political use and economic understanding of artifacts as "wealth goods" on two grounds. On the one hand, such assertions were commonly based on insufficient evidence. On the other, they do not take the specific use of the actual objects into 
account. The second point in particular highlights the fact that utilitarian items might also have been related to prestige, which the traditional attitude towards prestige goods neglects. Flad and Hruby (2007:10) stress that utilitarian goods, prestige goods, and wealth goods depend "on culturally specific values." Ultimately, it is their use and their inherent qualities that make artifacts prestigious (Flad 2007:109-111, 2011:16-34; Flad and Hruby 2007:9-11).

To be sure, such a refined explanation of prestige goods offers more analytical depth. Nevertheless, neither Flad and Hruby (2007), nor archaeological scholars in general, have devised a specific method that would enable archaeologists to identify particular objects or object groups that truly generated prestige for their proprietors (in addition to the references mentioned above, see Chapman et al. 2006; Dietler 2010; Graeber 2011; Higham et al. 2007; Miller 1987; Mizoguchi 2013; Mullins 2004, 2011; Trubitt 2000). This is largely because relevant studies take the concept of prestige to be common knowledge that warrants no further discussion. Stephen Shennan (2002:226) recognizes this issue when he writes that "archaeological discussions ... have made extensive use of the concept of prestige but have rarely been very specific about its nature." Archaeologists instead focus on the structuring qualities of so-called prestige goods as active agents in the social process. Shennan does not ameliorate the problem, however. On the contrary, even though specifically dealing with "prestige," he does not distinguish it from status (Shennan 2002:224-228). Such indiscriminate treatment of these two fundamental ideas invites closer scrutiny.

\section{STATUS VERSUS PRESTIGE}

Status in its most universal sociological definition denotes the position of an individual within society (Boudon and Bourricaud 1992:550) (Table 1). Anthropologists and

Table i. Various Parameters of Social Status Compared with Prestige

\begin{tabular}{|c|c|c|c|}
\hline \multicolumn{2}{|r|}{ SOCIAL STATUS } & \multicolumn{2}{|c|}{ PRESTIGE } \\
\hline BASIC & REFINED & BASIC & MAY BE BASED ON \\
\hline $\begin{array}{c}\text { Depends on } \\
\text { external } \\
\text { judgment }\end{array}$ & Education & $\begin{array}{l}\text { Depends on external } \\
\text { judgment }\end{array}$ & Material wealth \\
\hline Age & Intelligence & $\begin{array}{l}\text { One aspect of } \\
\text { social status }\end{array}$ & $\begin{array}{c}\text { Immaterial } \\
\text { qualities } \\
\text { ('virtues') }\end{array}$ \\
\hline Gender & Monetary wealth & $\begin{array}{l}\text { Equivalent to } \\
\text { German Ansehen }\end{array}$ & \\
\hline Occupation & $\begin{array}{l}\text { Command of physical force } \\
\text { Command of material goods } \\
\text { Presumed ability to control } \\
\text { physical phenomena } \\
\text { Ability to restore mental and } \\
\text { physical health } \\
\text { Obedience of others } \\
\text { Deference of others } \\
\text { Esteem of others }\end{array}$ & & \\
\hline
\end{tabular}


archaeologists often emphasize that this position is either ascribed or achieved. Following Ralph Linton, "ascribed statuses are those which are assigned to individuals without reference to their innate differences or abilities," while "achieved statuses are, as a minimum, those requiring special qualities, although they are not limited to these" (Linton 1936:115, emphases in original; also see Ames 2008:489; Foladare 1969; Peebles and Kus 1977). Ascribed status, then, comprises congenital characteristics such as race, gender, and age, whereas achieved status depends on past accomplishments. For instance, the status of the Queen of England is ascribed since she inherited the position from her father. Considering that being elected into office (ideally) rests on the political merits of the candidate, the status of the President of the United States of America is achieved. The latter point indicates that certain portions of a given society must concur on evaluative parameters when they judge the actions of each other (Homans 1974:197). What constitute merits to some observers are flaws to others. It follows that status is a relative and dynamic concept. Yet, the more pressing question is: what exactly are those parameters? Race, gender, and age are some of the basic variables that contribute to a person's social standing today. Further, the definition of ascribed status emphasizes that money or other forms of material wealth, along with subjective traits such as ambition, effort, performance, deference, obedience, or esteem received by individuals can enhance their social position (Boudon and Bourricaud 1992:551; Homans 1974:198).

Prestige has been defined, for instance, as (a) the standing or estimation of individuals in the eyes of people, or (b) their commanding position (Henrich and Gil-White 2001:168). On closer inspection, it becomes clear that this vision of prestige basically corresponds with the above explanation of ascribed status (Table 1). By invoking theoretical physicist Stephen Hawking as an example of someone who is "often said to have 'prestige'," Henrich and Gil-White (2001:167) attribute high status to a person who excels in a desired field. Similar to a host of other scholars in various disciplines, they equate the esteem signalers receive with the status they hold in society (Gould 2002:1147; Henrich and Gil-White $2001: 177)$. The notion of "esteem" is highly relevant for our understanding of prestige inasmuch as both concepts are usually used interchangeably (Goode 1978:3). However, George Homans (1980) makes the vital observation that esteem or prestige is but one of several constitutive dimensions of (ascribed and achieved) status (Table 1).

\section{Prestige as a Relative Concept: The Notion of Ansehen}

However ambiguous or vague the common explanations of prestige and status may be, they all concur that prestige describes some kind of positive veneration extended by responders toward signalers. The English term "esteem" in its sense of expressing a feeling of respect or admiration for someone indeed comes rather close to the point. The German word 'ansehen' describes the same attitude. Ansehen, used as a verb, literally means "to look up to someone or something," but has the advantage of also being used as a noun for the admiration that comes from looking up to someone or something. The following hypothetical examples demonstrate that assuming the onlooker's or responder's perspective is indispensable if one wishes to identify genuine prestige goods on the basis of mortuary evidence. 
In theory, there are two reasons for responders to look up to signalers. First, a person might be admired for their immaterial qualities. For instance, the general public still holds Mother Teresa's selfless actions in high esteem even though some concerns about her dogmatic religious and political views, supposedly questionable care for the sick, and purported mismanagement of donations have been raised (Larivée et al. 2013:326-332).

Second, individuals might be venerated due to their command of certain objects that make at least part of their admired qualities physically visible. According to Pierre Bourdieu's (1986:50-51, 1990) concept of objectified cultural capital, audiences might not only appreciate these individuals for the material and aesthetic appeal of the artifacts they possess, but also for having the intellectual expertise necessary to acquire and utilize them. Such items would be genuine prestige goods. Signalers may very well use them in active attempts to attract admiration or exert economic and political power over others as many archaeologist have argued, but it is essential to realize that such efforts need not necessarily have the desired outcome. Even more crucially, senders who do not consciously aim at garnering prestige may nevertheless be admired on account of certain goods in their possession. This claim is somewhat related to Flad and Hruby's (2007:9-11) assertion that utilitarian objects may also carry prestige. For example, a person may rely on the support of an antique cane that means nothing to most onlookers, but some observers might recognize it as something special and admire its owner for his or her good taste and the financial means to acquire such an exquisite and exclusive item.

Accepting the relative insignificance of the intentions of senders, however, is essential to understanding the phenomenon correctly. Ultimately, responders decide whether the behavior or objects of signalers genuinely generate prestige, that is, ansehen. This is best explained by another hypothetical example. Nowadays, expensive and powerful sports cars are often referred to as prestige goods. Viewers who appreciate the technical sophistication, power, aesthetics, and potential to attract attention that is inherent in such automobiles would agree, but these cars might mean something entirely different to other observers. Some might not find them aesthetically pleasing; others might regard them (and by extension their owners) as incarnations of the evils of cut-throat capitalism. Some environmentalists would condemn the waste of natural resources that goes along with gas-guzzling sports cars. Therefore responders in any given society or even members of a single social class are hardly ever likely to unanimously agree on what constitutes prestige or prestige goods. Some individuals will always hold certain skills, virtues, or objects in highest regard, whereas others will not care about the same skills, virtues, or associated objects in the slightest. Thus, rather than ascribing universal structural significance to prestige and prestige goods, it is more appropriate to focus on the significance ascribed by small sets of individuals such as groups, cliques, or extended families (DeMarrais 2011:165-166; Freeman 1992; Homans 1950; Mokken 1979; Moody 2001; Richerson and Boyd 2001:458).

In sum, prestige is not equivalent to social status, although it is a contributing dimension to it. Prestige is also not exclusively and solely generated by material wealth, as it can also be attributed through personal traits such as wisdom, selflessness, or other qualities a certain set of individuals regard as valuable. The German noun ansehen most aptly describes how prestige is generated by people (responders) with shared core values who look up to signalers who command more of the skills and traits they value (Table 1). 
IDENTIFYING PRESTIGE GOODS IN ARCHAEOLOGICAL CONTEXTS: RELATIVE VALUE, PRESTIGE, AND EMULATION

Taking this more nuanced understanding of prestige as a steppingstone, the most pressing question becomes: How does prestige relate to mortuary data? Material remains preserved in tombs usually do not directly reveal any of the immaterial qualities of the deceased. In addition, archaeologists are missing information on whether certain artifacts were intended to enhance the social profile of their owners. They are also lacking clues as to how the larger society surrounding the proprietors perceived those objects.

An even more fundamental issue is at stake: Are mortuary data even suitable for inferring social significance? In the past, two strands of archaeology have extensively discussed this question and proposed almost diametrically opposed answers. Essentially, proponents of the so-called "New/Processual Archaeology" regard the quantity and quality of burial goods recovered from any given cemetery as direct reflections of past social structures. The more wealth accumulated in a tomb, the higher the status of its occupant (Binford 1971; Saxe 1970). In contrast, post-processual archaeologists emphasize that this straightforward correlation cannot be taken for granted. The burial itself was but the final act in possibly quite a long list of funerary rituals that may have served to exaggerate the actual social position of the deceased (and ultimately also supposed to boost the status of the bereaved). Thus, a much larger number of objects of substantially higher quality might be unveiled from a grave than the dead individual would have been able to command during his or her lifetime (Morris 1992:1-30; Parker Pearson 2000:9). There is no need to go into more detail here, since the debate has already been extensively covered in previous scholarship (Flad 2000:5-9; O'Shea 1984:3-22). Suffice it to say that my argument works in either case, since it focuses on the effect material culture has on an audience rather than the intentions of the deceased or their survivors. For our purposes, it is of secondary importance whether a lavishly decorated garment cut from the finest fabrics available at the time was thought to impress observers while the owners themselves were hosting a magnificent feast or while they were lying fully clothed on a bier for all guests to see during a funerary feast. The key is that at least some audience members held the dead individuals or their descendants in greater esteem on account of the garment.

The difficulty for archaeologists is finding evidence of such instances of admiration. I propose that the act of emulation and its physical expression in any kind of material culture provides a way to pinpoint prestige and identify genuine prestige goods in mortuary contexts. Emulation must not be mistaken for imitation, however. Richerson and Boyd (2001:446) argue that imitation encompasses the adaptation of the entire behavior of a single person. Out of several dozens of individuals, observers choose the one whose behavior they find most beneficial. The implication for the example of elaborate attire is that onlookers would not just copy the piece of clothing itself, but also adopt the habitus of the deceased that goes along with wearing it (Bourdieu 1990). Obviously, this is very difficult to accomplish if guests only laid eyes on the deceased for the first time at the funeral ceremony. Considering that funerals were venues of social competition that involved large audiences (Hayden 2009:32-33), we cannot assume that the deceased or their living relatives were personally acquainted with every single guest. Unlike imitation, the act of emulation does not attempt to duplicate every aspect of the behavior of another human being, but only a fraction of it. Emulation 
focuses on copying the results of actions instead of the actions themselves (Tennie et al. 2006:1159-1161). Emulating nice attire (and other kinds of material culture) expresses one person's appreciation for the visual representation of another person's behavior. The admiration of responders may have deeper roots in the actions of signalers - that is, responders may actually imitate signalers - but this need not always be the case.

The argument presented in the previous section suggests that the notion of ansehen/ prestige invariably entails positive value judgments on the part of the recipients. However, object value in itself is a highly complex issue that is usually tied up in the discourse surrounding prestige goods (Papadopoulos and Urton 2012; Renfrew 2012). As the common assumption goes, the more exotic or rare an item, the higher its value. Although still arguing within the limits of this framework, Rowan Flad (2012) urges a more profound approach. Building on the work of Arjun Appadurai (1986) and Igor Kopytoff (1986), he insists that researchers should consider the social context in which an item was used and, even more importantly, acknowledge that its social contexts might have changed over time. Object value is therefore a dynamic concept that requires us to look at all stages of an object's biography, including its production, use, and eventual disposal (Flad 2012:309-312).

Any quest for genuine prestige goods in mortuary contexts must thus start with an assessment of the relative value of the objects under review. In what follows, I develop a set of seven specific criteria to help in establishing the relative value of any object with some degree of certainty. First, relative high production and acquisition costs of items are the most widely accepted features of prestigious quality, as these costs guarantee a degree of exclusivity. It is safe to assume that ownership of costly objects was admired by people in ancient times. Thus, two aspects of the relative value of a material or object may be examined: (1) its high cost relative to other finds in the archaeological assemblage; and (2) its "intrinsic value," that is, the worth a given society or culture ascribes to an object based on shared norms. As mentioned briefly above, the different degrees of appreciation of gold and other metals in Neolithic Europe and jade in Neolithic China are examples of the "intrinsic" aspect of relative value. Appadurai (1986:34) and Renfrew (2012:259) therefore suggest substituting "prime value" for "intrinsic value." Directly related to the prime value of any good is the availability of raw materials (second criterion) and the labor intensity and technical expertise required to produce it (third criterion) (Flad 2012:310; Hayden 1998:12).

Relative intrinsic value may relate more strongly to the fourth criterion, exoticism. Artifacts whose nature or provenance were perceived as exotic could have appealed to some observers. Such exotic items were often rather costly, but not necessarily so (Appadurai 1986:38; Miller 1987:122). Mary Helms (1992:159) maintains that prestige could be gained by traveling to distant places in order to "obtain politically and ideologically useful materials." Imbued with the aura of the unknown, artifacts from far away realms could evoke feelings of appreciation, admiration, or longing among the uninitiated in one's native country. The only ones to decipher their hidden meanings were the travelers who acquired them (Helms 1992:159-160, 1993:101-108, 173-191). Exotic objects represent cultural and symbolic capital in Bourdieu's (1977, 1986, 1990) sense.

A fifth criterion for assessing relative value relates to items that were subject to social restrictions (Appadurai 1986:38; Kopytoff 1986:74). According to the distinction between status and prestige laid out above, such items would be treated as status symbols. It is important to keep in mind, however, that status symbols do not 
necessarily induce prestige as defined here (Barkow 1975:558). For instance, the crown and scepter as symbols were inextricably linked to medieval European kings. Judging from the perspective of suppressed and exploited subjects of some iniquitous regents, these symbols did not inherently foster universal admiration of those kings.

A sixth criterion is based on archaeologists analyzing the special position or nature of certain finds within burial good assemblages (Flad 2012:310; Renfrew 1986:148). Objects placed in special positions may not only have been of particular importance to the burial ritual itself, but also served a special function during the tomb occupant's lifetime. Seventh, a find might be identified as an heirloom object. The longer the biography of an object, the greater the chance that it has accumulated additional, ideologically charged meanings (Flad 2012:310; Fogelin and Schiffer 2015; Gosden and Marshall 1999; Kopytoff 1986; Stahl 2010).

The following list summarizes the seven criteria for assessing the relative value of an archaeological object:

1. Relative high production or acquisition costs (suggesting exclusiveness)

2. Availability of raw materials

3. Labor intensity and technical expertise in production

4. Exoticism

(a) Nature of object itself

(b) Provenance

5. Social restrictions

6. Special character in context of tomb assemblage

(a) Nature of object itself

(b) Position in tomb and in relation to body

7. Heirloom

I contend that the higher the relative value of an item, that is, the higher number of the seven criteria apply to objects recovered from burials, the likelier it was regarded as a genuine prestige good by appreciative viewers. Such artifacts may very well have generated ansehen among some responders. This can only be safely assessed using the litmus test of emulation, however. Copies and their originals must stem from geographically related tombs that date from at least the same era. Ideally, burials that yield copies would date slightly younger than tombs that contained originals, since the goal for the archaeologist is to demonstrate that the copies were produced in reaction to originals. In order to add another layer of certainty, special attention needs to be paid to criterion seven, the position of the finds within the respective tomb assemblages. It seems plausible to assume that copies being placed on the body of the deceased or in the burial chamber in the identical positions of contemporary originals would indicate that the copies and originals had comparable functions.

\section{EMULATION OF SILK FABRICS IN TARIM BASIN BURIALS}

\section{Tarim Basin Sites and Archaeological Materials}

Here I analyze silk finds from a total of 79 tombs that date from the second through early fifth centuries C.E. (Table 2). The tombs are distributed across four cemeteries along the so-called Southern Route of the Silk Road (Hansen 2012:6). As this epithet indicates, the Loulan (Lopnor) 樓蘭, Yingpan 營盤, Zhagunluke 札滾魯克 (Uyghur: Charchan), and Niya 尼雅 graveyards are located at the southern rim of the Tarim 
Table 2. Statistical Analysis of Silk Finds by Weave Type in Tarim Basin Burials

\begin{tabular}{|c|c|c|c|c|c|c|c|c|c|}
\hline & \multirow[b]{2}{*}{$\begin{array}{l}\text { NO. TOMBS } \\
\text { PER SITE }\end{array}$} & \multicolumn{2}{|c|}{$J U A N$ 絹 } & \multicolumn{2}{|c|}{ QI 綺 } & \multicolumn{2}{|c|}{$J I N$ 錦 } & \multicolumn{2}{|c|}{$\overline{T A Q U E T E ́}$} \\
\hline & & $\begin{array}{l}\text { NO. } \\
\text { TOMBS }\end{array}$ & $\begin{array}{l}\% \text { OF } \\
\text { TOTAL }\end{array}$ & $\begin{array}{l}\text { NO. } \\
\text { TOMBS }\end{array}$ & $\begin{array}{l}\% \text { OF } \\
\text { TOTAL }\end{array}$ & $\begin{array}{l}\text { NO. } \\
\text { TOMBS }\end{array}$ & $\begin{array}{l}\% \text { OF } \\
\text { TOTAL }\end{array}$ & $\begin{array}{l}\text { NO. } \\
\text { TOMBS }\end{array}$ & $\begin{array}{l}\% \text { OF } \\
\text { TOTAL }\end{array}$ \\
\hline Lopnor & 13 & 11 & $84.6 \%$ & 7 & $53.8 \%$ & 10 & $76.9 \%$ & 0 & $\mathrm{n} / \mathrm{a}$ \\
\hline Yingpan & 29 & 18 & $27.6 \%$ & 5 & $17.2 \%$ & 6 & $20.7 \%$ & 4 & $13.8 \%$ \\
\hline Zhagunluke & 25 & 6 & $24.0 \%$ & 2 & $8.0 \%$ & 6 & $24.0 \%$ & 8 & $32.0 \%$ \\
\hline Niya & 12 & 5 & $41.7 \%$ & 2 & $16.7 \%$ & 5 & $41.7 \%$ & 0 & $\mathrm{n} / \mathrm{a}$ \\
\hline $\begin{array}{l}\text { Total tombs } \\
\text { with silk finds }\end{array}$ & 79 & 41 & $51.9 \%$ & 16 & $20.3 \%$ & 27 & $34.2 \%$ & 12 & $15.2 \%$ \\
\hline
\end{tabular}

Basin, which sits roughly at the center of today's Xinjiang Autonomous Region (Fig. 1). In the early twentieth century, Sven Hedin (1937) and Aurel Stein (1928a, 1928b) were the first to partially excavate these sites. Since the late 1960s, Chinese and Japanese archaeologists have revisited them on a regular basis and produced a steady stream of excavation reports. ${ }^{1}$ The following arguments are based on the findings of early European explorers and more recent Chinese archaeologists. It is worth noting that more than the 79 tombs discussed here are known from the four sites. Many are extremely poorly preserved since most of them have been looted or flooded at least once over the past century. In addition, a small number of more or less well-preserved burials have already been excavated, but still await publication. Thus, readers may catch glimpses of finds that completely lack archaeological context. These extraordinary artifacts are usually textiles that appeared in exhibition catalogues or individual studies.

A few burials surprised the excavators by yielding well-preserved mummies and clothes. The finds from ostentatiously furnished tombs such as 95MN1M3 and 95MN1M8 at Niya and 95BYYM15 at Yingpan (source of the so-called "Yingpan Man") feature in almost every book or article on the early Silk Road. Their occupants wore several layers of extravagant silk (as well as cotton and wool) garments and spare attire was placed in their tombs. Occasionally, they were covered by large silk blankets. However, we must not treat these remarkable burials as default yardsticks for comparison, especially when we are interested in textile finds. Even though Tables 2 and 3 gather a fair number of tabby and jin-silk fabrics that emerged from the Tarim Basin tombs, most of them were not nearly as well stocked as 95MN1M3, 95MN1M8, and 95BBYM15. Table 2 includes tombs that might have yielded several square meters of various kinds of silk fabrics along with burials that might have contained just a single fragment of silk cloth. The percentages of tombs that yielded silks listed in this table need to be viewed against this backdrop. A similar caveat concerns clothes that surfaced from the Tarim Basin tombs. Apart from the apparel yielded from 95MN1M3, 95MN1M8, and 95BYYM15, a few other garments were almost fully preserved, but even these pieces were partially decayed at spots that were in direct contact with the skin of the deceased. Unless there are clear traces of mending, it is almost impossible to determine whether such attire was worn while the deceased was still alive.

As for the tomb assemblages, every single site revealed burials that contained finds to which at least two of the seven criteria of relative value apply. In general, the standard equipment found in the assemblages fails to conform to more than one criterion, although some of the artifacts likely were somewhat costly. The bulk of the common 


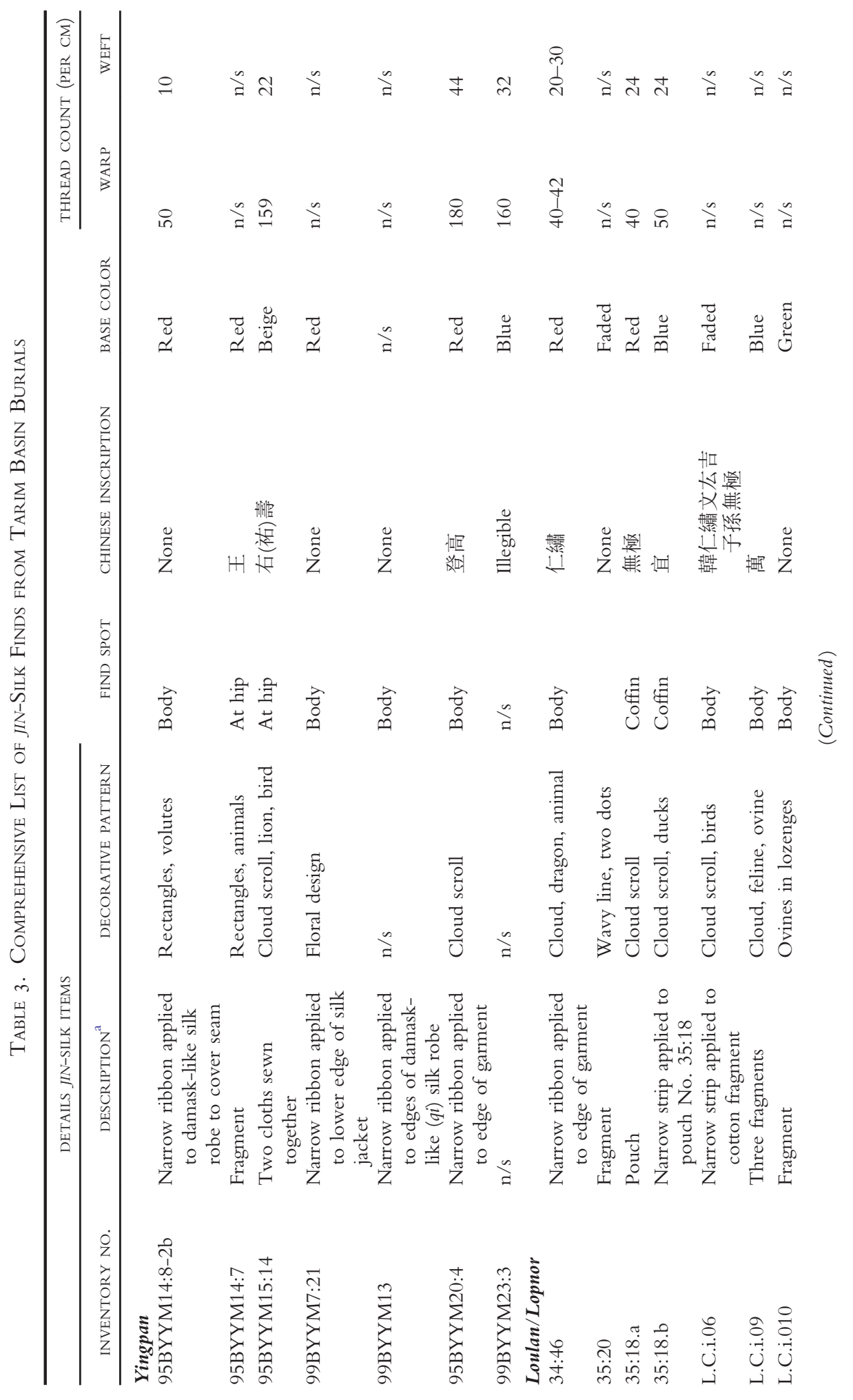




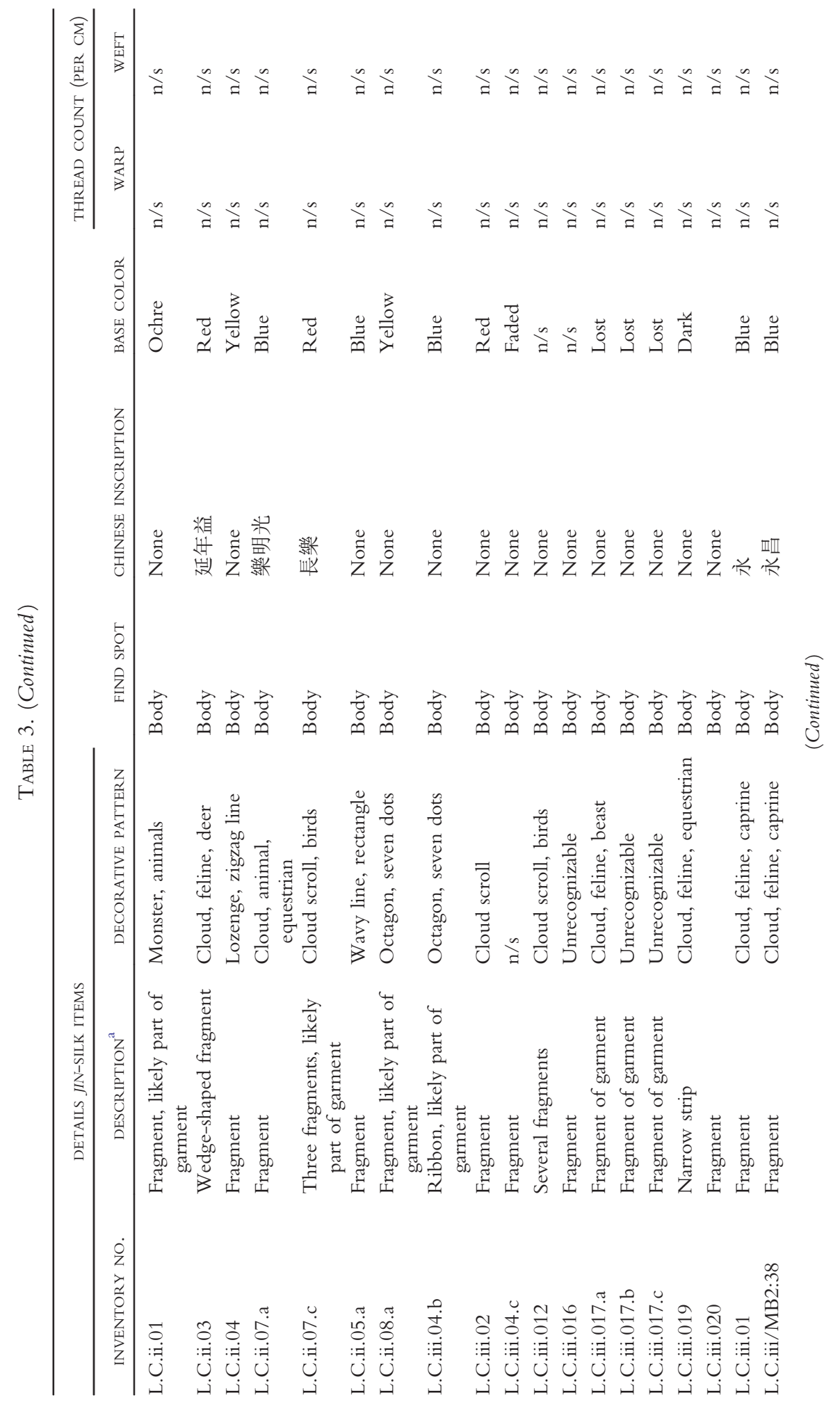




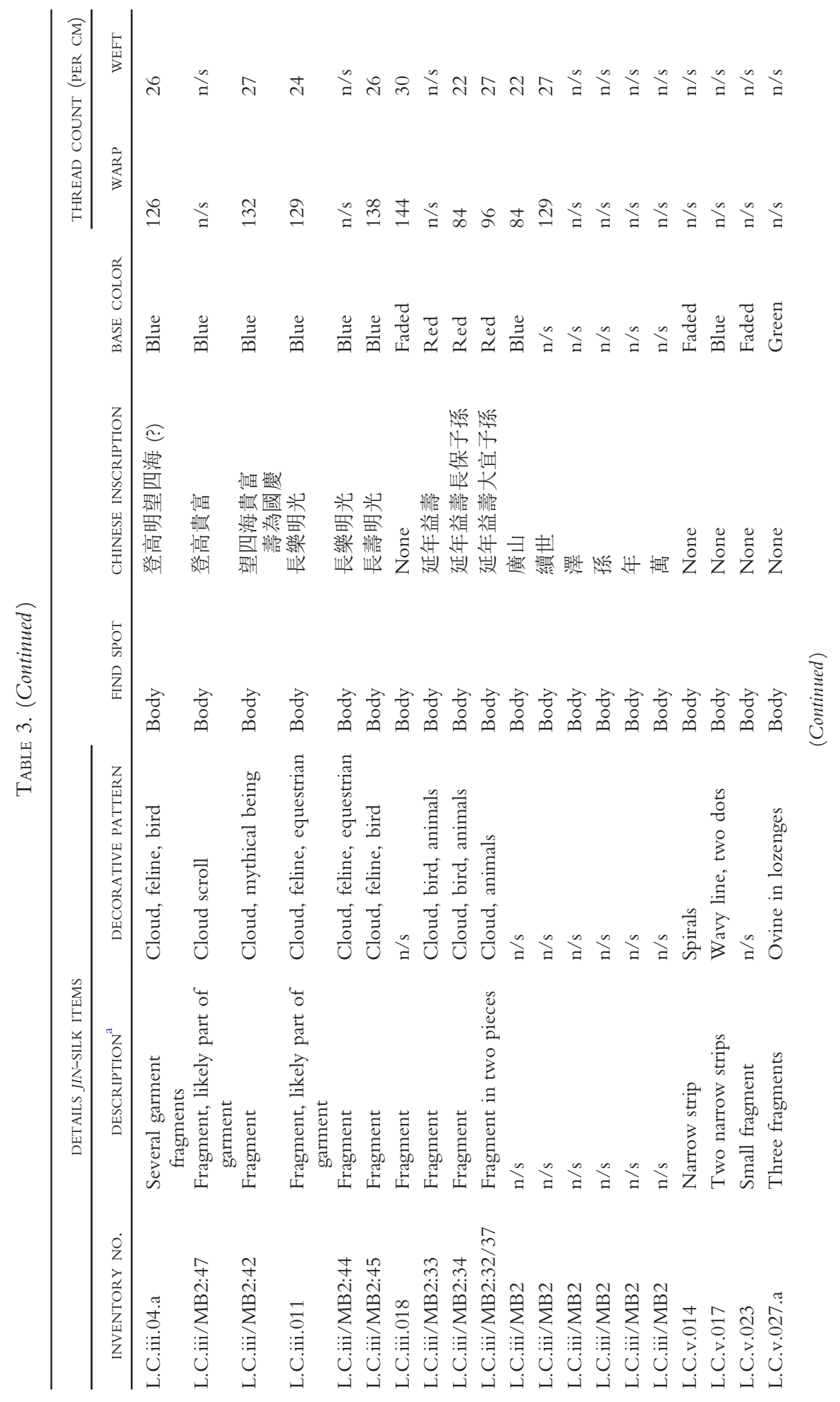




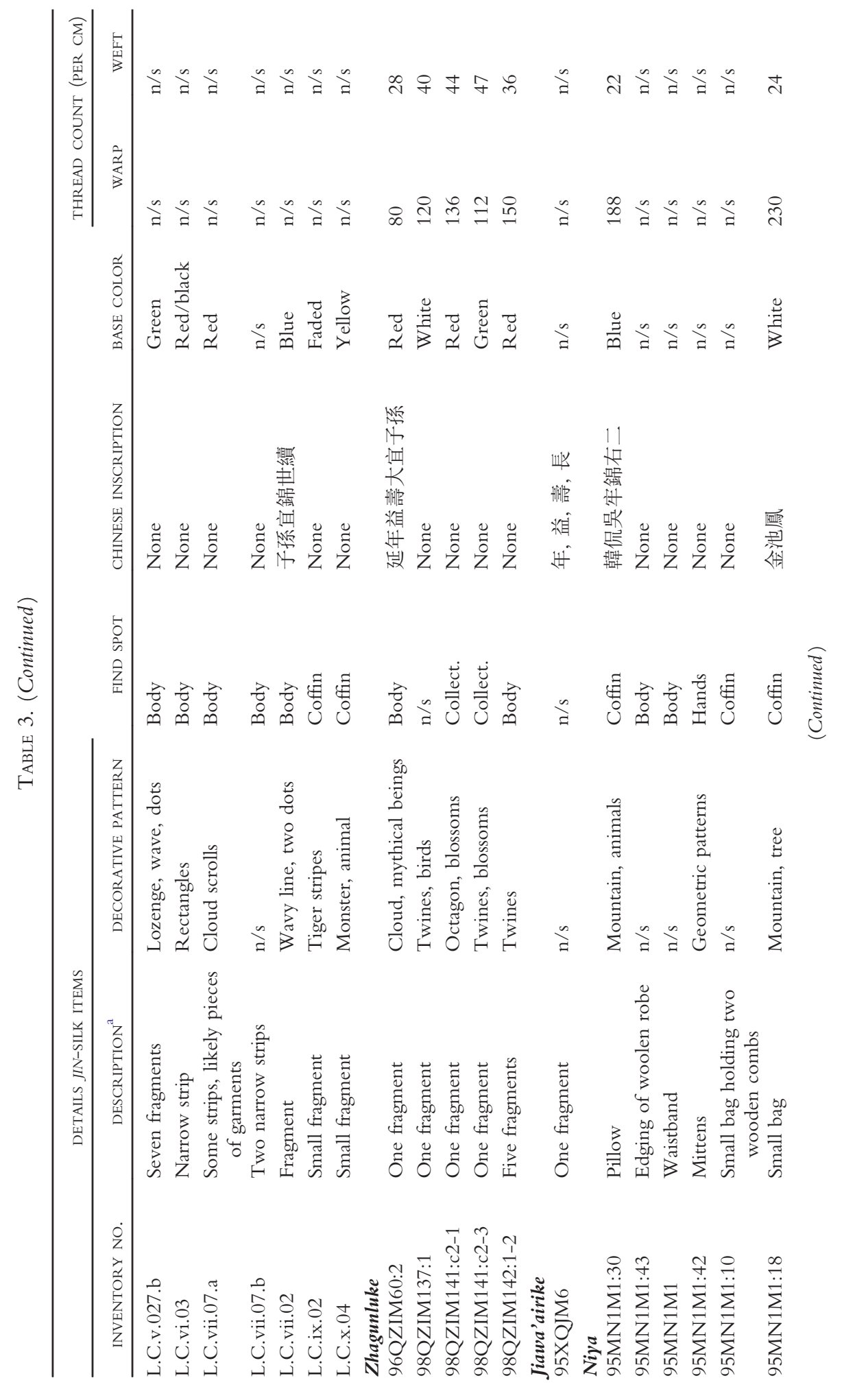




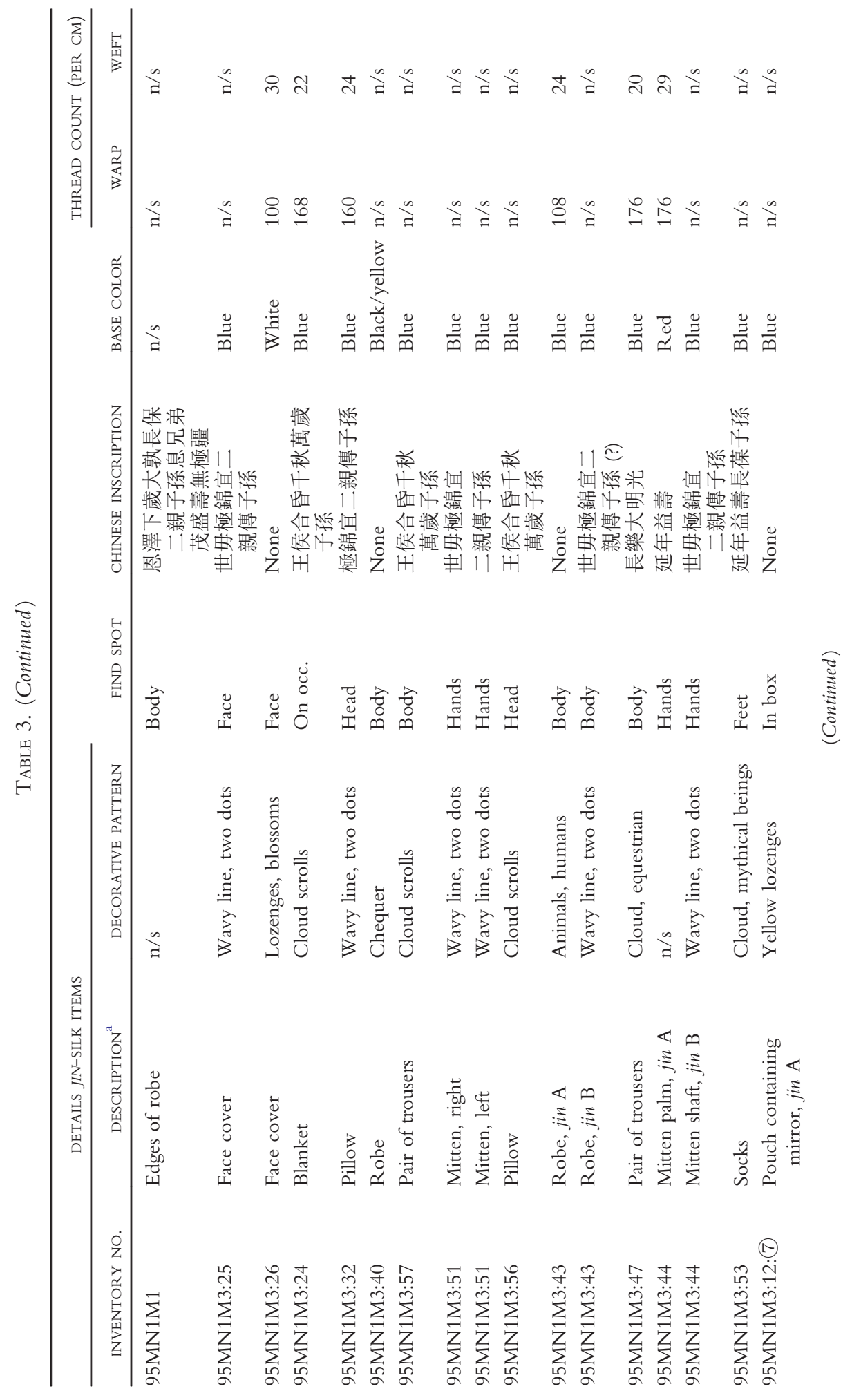




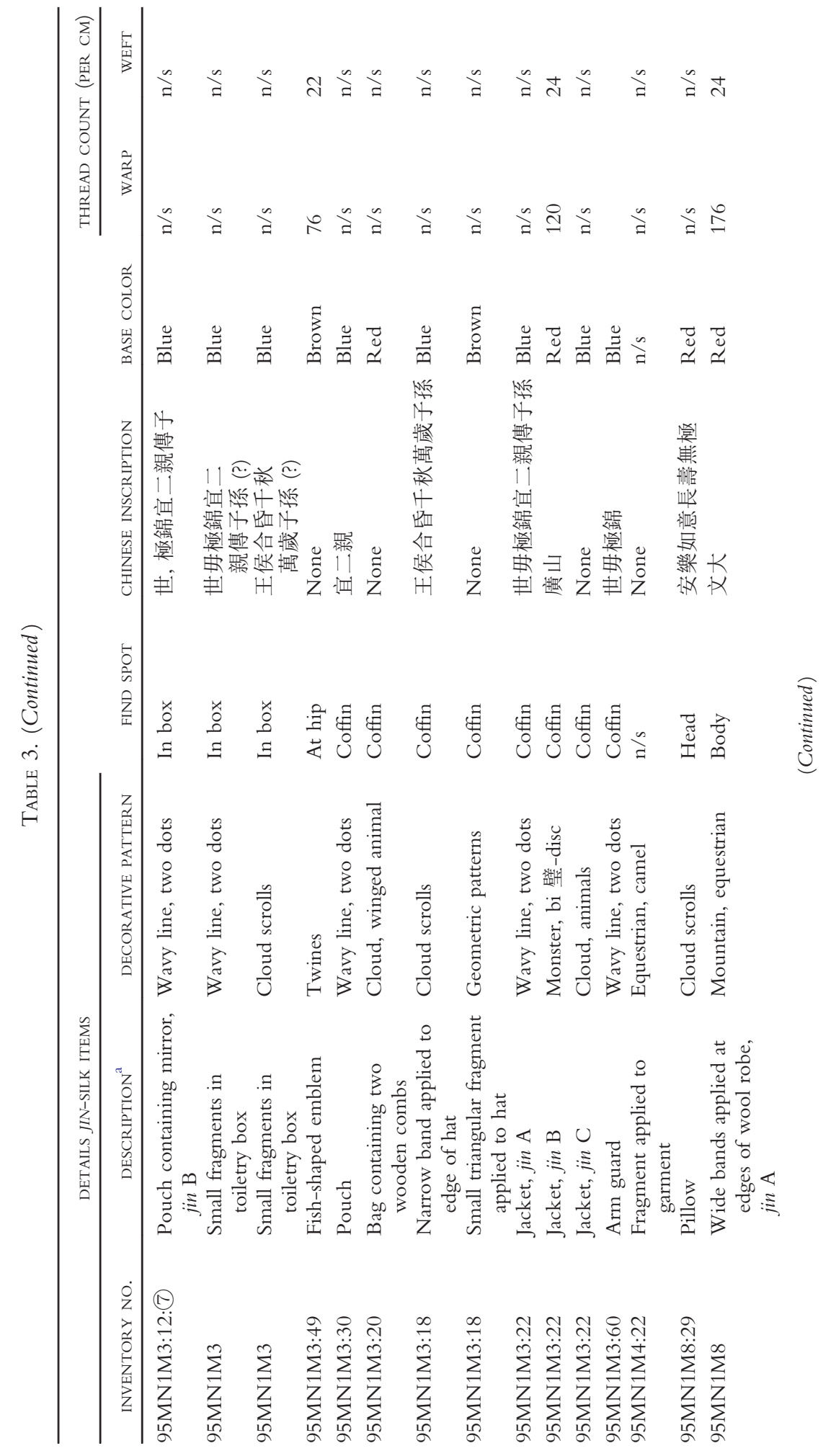




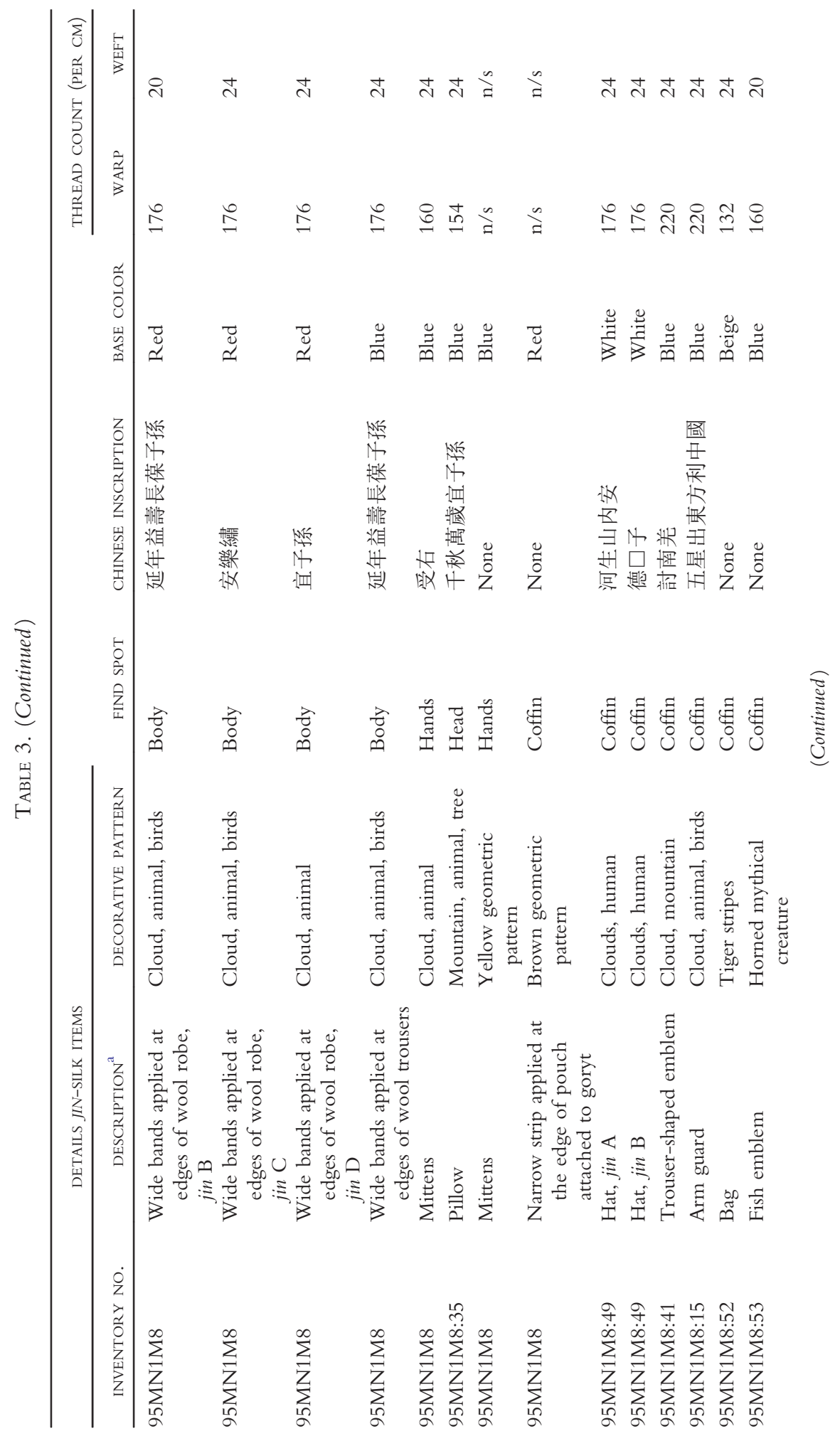




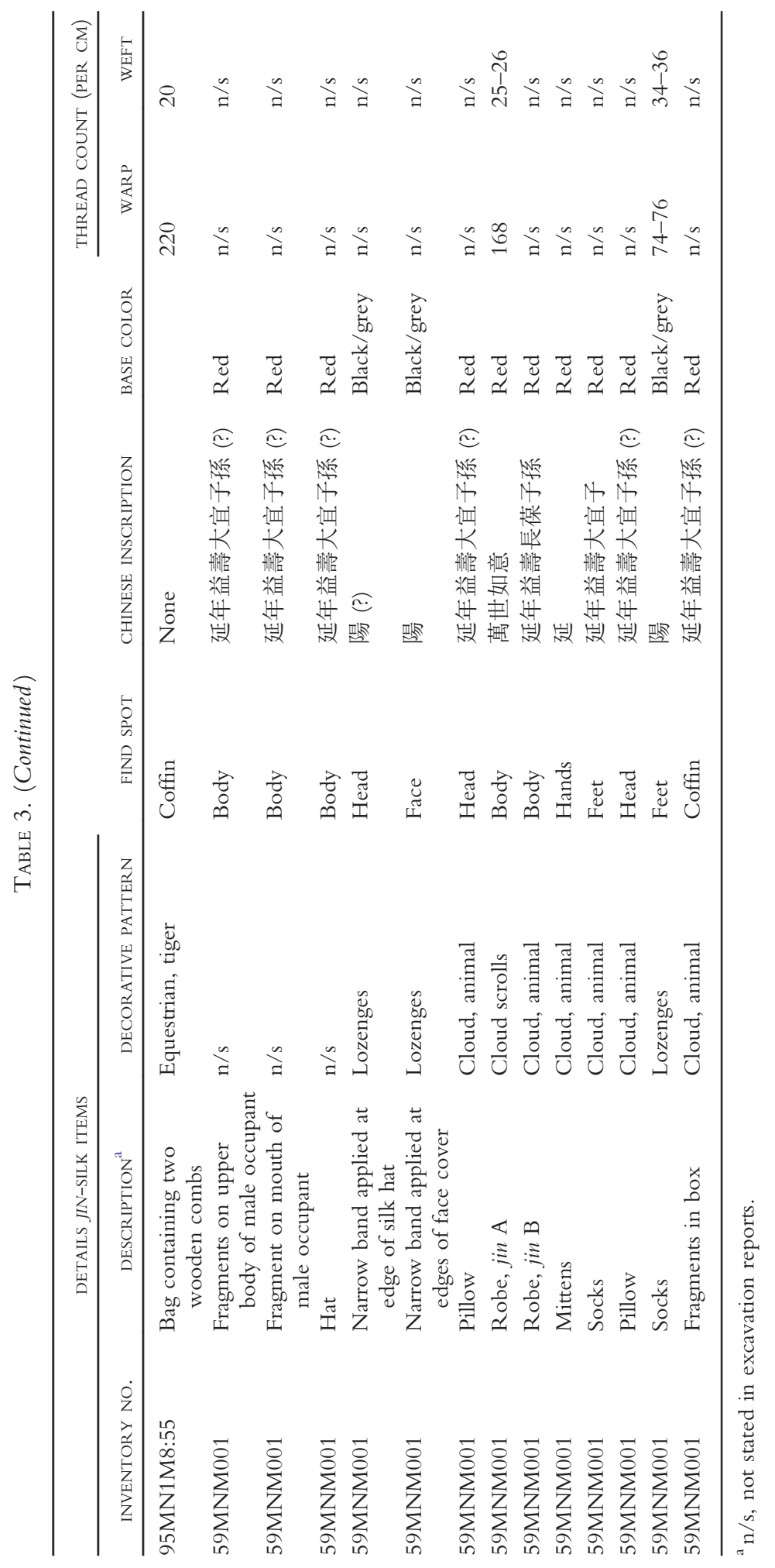


grave goods comprised indigenous products such as woolen clothes, composite bows, the occasional iron knife, some wooden saddles, wooden tableware, and many other small finds made from wood or leather. About one half of the burials featured a few high quality items that might qualify as prestige goods. The bronze mirrors, silk fabrics of various weaving patterns, and glass beakers certainly came at high acquisition costs and, as imports from either China or Western Asia, were surely fairly exotic. For the sake of brevity, I next focus on assessing the relative value of silk fabrics in accordance with the seven criteria established above. I then argue that the emulation of warp-faced compound tabby weaves (jin 錦) mark them as genuine prestige goods.

\section{Introducing Silk Fabrics}

During the second through early fifth centuries C.E., silk was still a foreign and somewhat exclusive commodity in the Tarim Basin. So far, no evidence has been found of local silk production. As Yü Ying-shih (1967:151), a historian of early imperial China, states: "Of all the goods exported from Han China, silk was the single commodity that was the most cherished by foreign peoples." The term "silk" has been indiscriminately employed as a catch-all phrase for a variety of fabrics that all made use of the same raw material: immensely long, sturdy silk threads. The high prime value of finished silk cloth is easily understandable. All types of silk cloth were the product of a very time-consuming process that called for very specific resources and expertise even before weaving could begin. The caterpillars of domesticated silk moths (Bombyx mori) only feast on leaves of White Mulberry trees (Morus alba) until they prepare themselves to metamorphose by spinning a cocoon using a single thread up to nine hundred meters long. Breeders had to boil the cocoon to kill the caterpillar before its metamorphosis was completed to prevent the fully-fledged moth from cutting through the thread. Several single threads would be reeled into a thicker thread, which was suspended onto a loom (Selbitschka 2010:147-148). Even before the process of weaving began, the silk threads corresponded with criteria 1-3: high production costs; not readily available in the Tarim Basin; and requiring considerable skill (growing Mulberry trees and breeding silkworms).

By the fifth century C.E., the ancient Chinese had mastered the production of three main types of silk cloth, distinguished by different weaving patterns:

1. Juan 絹: simple tabby cloth built by interlacing warp and weft threads

2. Qi 綺: technologically sophisticated, monochrome, patterned, damask-like weave

3. Jin 錦: even more complex polychrome, patterned, warp-faced, compound tabby weave

All three types of cloth are known from written sources and scattered burial sites. A small number of graves at Zhagunluke and Yingpan revealed another type of silk cloth, however:

4. Taqueté: polychrome, patterned, weft-faced, compound tabby weave. ${ }^{2}$

\section{Assessing the Relative Value of Simple Tabby Silk (juan)}

Comparatively simple tabby weaves (juan) figure most prominently among the silk textiles from Tarim Basin burials (Table 2). Seeing that 41 out of 79 tombs $(51.9 \%)$ yielded this kind of cloth, it does not seem terribly exclusive at first glance. Nonetheless, the fact that the majority of occupants were wearing woolen clothes 
shows that even this kind of silk cloth was by no means available to everyone. Entire garments tailored from tabby silk are also the exception. Most of the finds listed in Table 2 are small pieces of fabric and ribbons that were applied to various kinds of clothes and accessories. The high relative value the local population placed on these silk fabrics is further attested by the recycling of even the smallest fragments in order to decorate tiny pouches (Xinjiang Wenwu 1999a:10, 2002b:7, 9).

By the third century C.E., Tarim Basin societies had widely adopted silk tabby weaves as currency. This is evident from Kharosthi texts that have been found in the settlement sites of the Loulan region and Niya. Kharosthi (a.k.a., Gandhari) was a northern Indian script that was used by the indigenous population to transcribe the northern Indian Prakrit dialect then prevalent among Tarim Basin residents (Salomon 1996). One document tells us that tabby silk was owed to Chinese merchants by members of the indigenous population (Burrow 1940:1, no. 3). Another states that a buyer acquired a female slave for the amount of 41 bales of tabby silk (Burrow 1940:9, no. 35). A third record conveys that at least some Buddhist monks were prone to physical violence against fellow clergymen: depending on the severity of their physical altercations, fines between 5 and 15 bales of tabby silk were ordered (Burrow 1940:95, no. 489). ${ }^{3}$ The fact that tabby silk was adopted as currency suggests that it may not have been the most exclusive and exotic good, but its restriction to roughly one half of the tombs under review as well as its highly economic use therein still render it a rather valuable product. Finally, extracting tabby silk currency from circulation for whatever reason meant destroying wealth. Only people of certain means would have been able to do that.

\section{Assessing the Relative Value of Warp-Faced Compound Tabby Silk (jin)}

In total, 27 out of 79 tombs (34.2\%) yielded polychrome warp-faced compound tabby weaves (jin) (Table 2). As for the juan finds discussed above, this number must not be overemphasized, since the tombs contained anything from miniscule fragments to entire blankets (Table 3). Contemplating the sheer complexity of jin-silks along with their aesthetic qualities, such fabrics seem at first glance to be quintessential prestige goods. Made from silk threads of between two and five different colors they were (and still are) a mesmerizing sight regardless of what different individuals might have thought of them (not unlike the aforementioned sports cars) (Fig. 2). They also share, of course, a prime value based on their technical refinement. For instance, one piece of $46 \mathrm{~cm}$-wide cloth was discovered in tomb 95MN1M8 at Niya; it had been woven with a density of 176 threads per centimeter (Table 3). This means that more than 8000 threads of four different colors would have been arranged on a highly complex loom, while taking intricate decorative patterns such as Chinese characters into account (Wang et al. 1999:103). ${ }^{4}$

Chinese historiography reports that during the late first century B.C.E. and early second century C.E., government workshops had to be closed because the production costs of silk surpassed the financial means of the imperial court to pay for it (Hanshu 1962, chap. 19A:732). A glance at the archaeological record even suggests the exact monetary value of jin-silk within the Tarim Basin societies, since a $52 \mathrm{~cm} \times 24 \mathrm{~cm}$ fragment retrieved from a tomb at Loulan bore the following Kharosthi ink inscription: "Polychrome patterned [silk] of Bimva Srihetasa, [worth] one hundred [pieces of] money" (Xinjiang Loulan 1988:34). We have no way of knowing whether this pricetag referred to just the small fragment yielded by the tomb or if it originally labeled a 


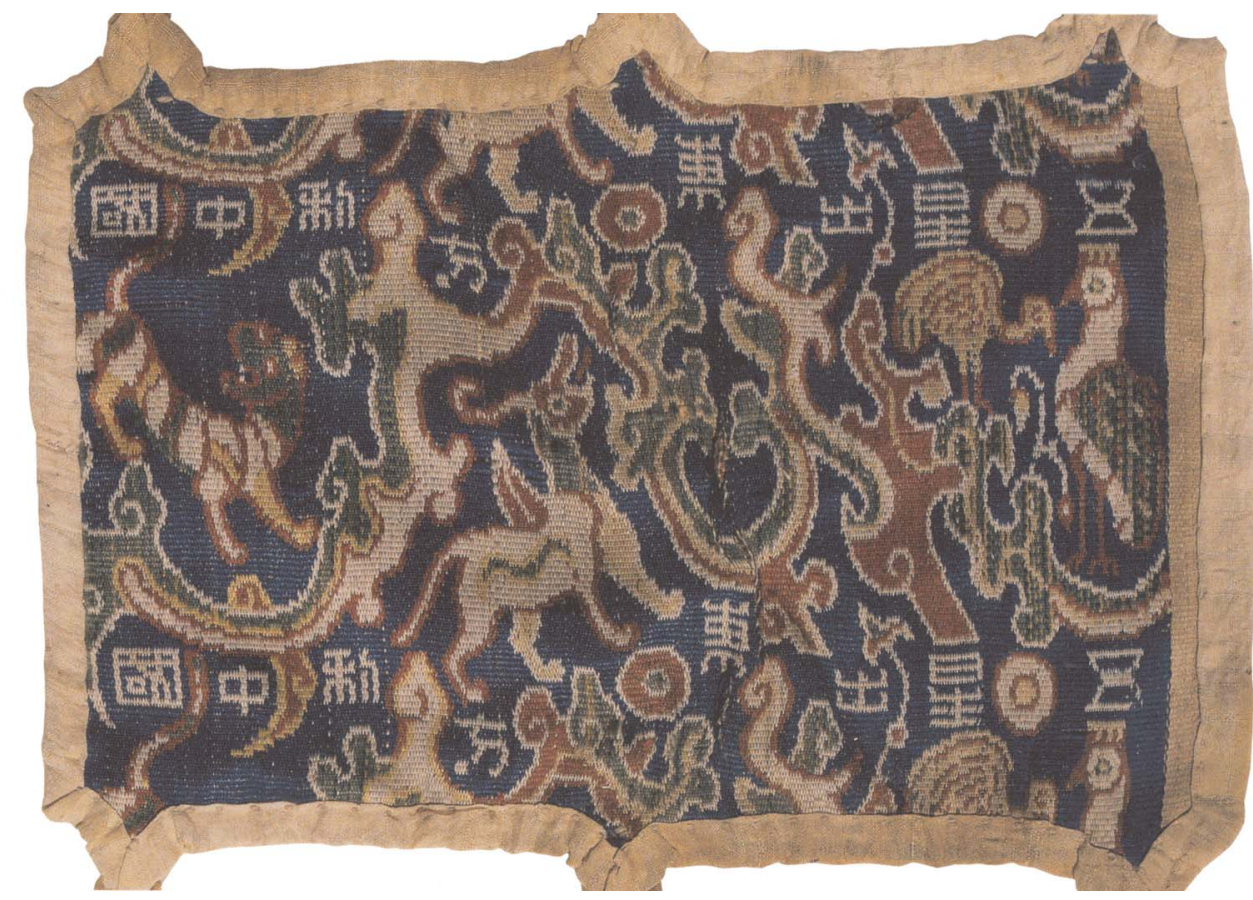

Fig. 2. Arm guard made from polychrome patterned warp-faced compound tabby silk with inscription “五星出東方利中國 [Five stars arise in the east to benefit the Middle Kingdom],” Tomb No. 8, Niya cemetery No. 95MN1 (after Zhao and Yu 2000:63, fig. 24.f).

much larger piece of fabric, however. Furthermore, we can only speculate about the relative value of "one hundred pieces of money," since our knowledge of the purchasing power of coins in the Tarim Basin during the second to fifth centuries C.E. is almost nonexistent (Wang 2004:31). Be that as it may, even without knowing the exact monetary value of jin-silks, they easily meet criteria 1-3: their production costs were immense; silk threads were unavailable in the Tarim Basin; and the amount of labor and technical expertise to weave them was enormous.

Jin-silks also seem to have met criterion 5. Another Hanshu passage mentions that social restrictions were imposed on the possession of this type of silk cloth. According to a decree dating from 199 B.C.E., merchants were strictly banned from acquiring as well as wearing clothes made from monochrome and polychrome patterned silk (Hanshu 1962, chap. 1:65, chap. 24B:1153; Swann 1950:231). This made jin-silks a highly exclusive commodity. (How Tarim Basin societies got access to them is discussed below.)

Moreover, the elaborate designs of polychrome warp-faced compound tabby weaves added to their exotic appearance, which meets criterion 4. Landscapes of mountains and clouds populated by dragons, tigers, or riders on horseback (Figs. 2, 3, Table 3) are familiar motifs in the art of the Han Period (206 B.c.e. 220 c.e.) (Linyi 1984:48-49; Liu 2006:36-40). To the eyes of the local population, such patterns must have looked fairly peculiar. Mary Helms' (1992:159-160, 1993:101-108, 173-191) notion that a mystical aura surrounds strange iconography comes to mind. The air of exoticism that wafts around mythological sceneries only thickens when they are interspersed with woven Chinese characters. Indigenous observers would have had to 

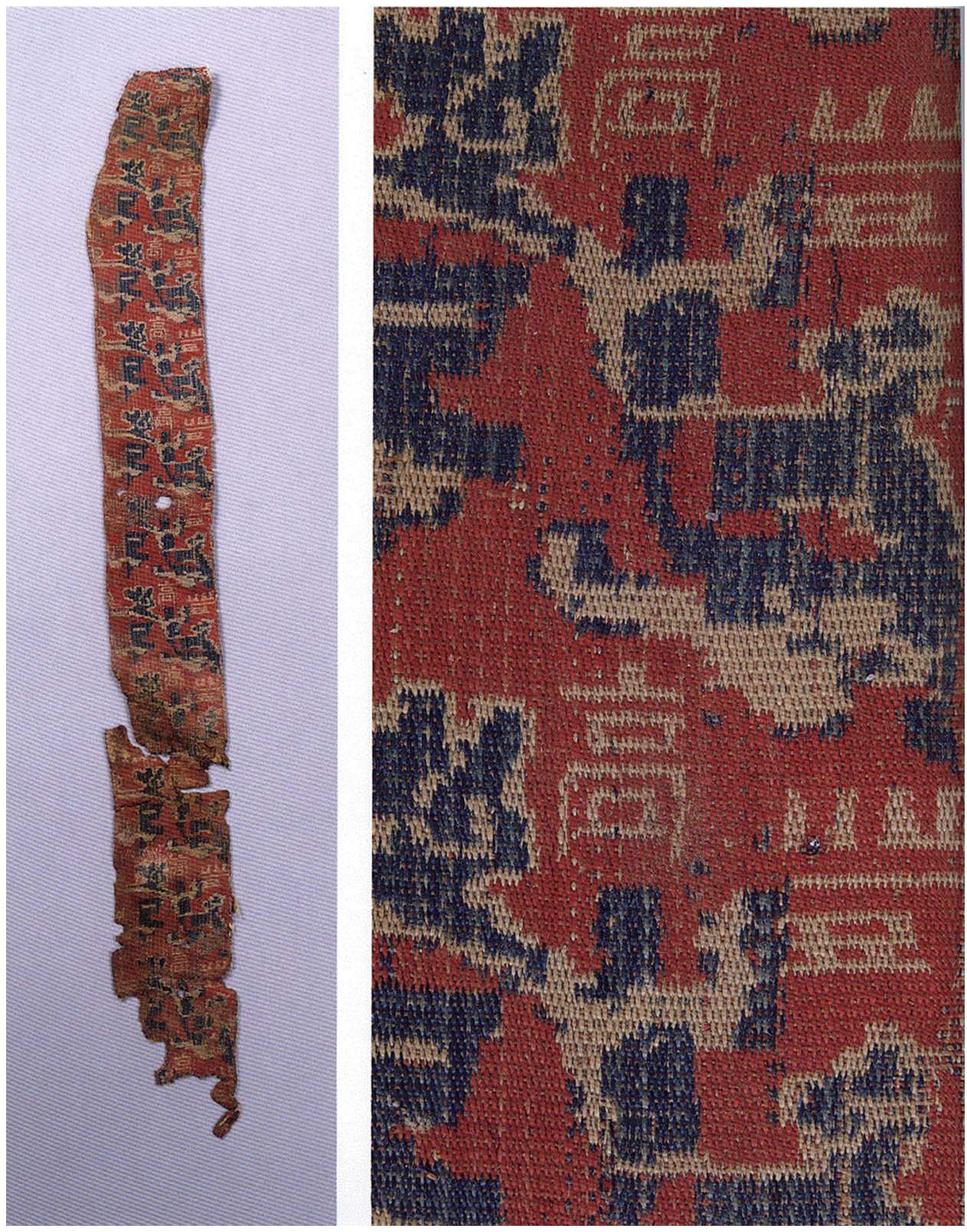

Fig. 3. Fragments of silk polychrome patterned warp-faced compound tabby weave with inscription “deng gao 登高 [(may you) ascend (lofty) heights]” adorning front edge of occupant's robe, Yingpan Tomb No. 95BYYM20 (after Zhao and Yu 2000:42, fig. 10).

command considerable cultural capital to read such alien imagery and writing. Judging from the abundance of Kharosthi documents discovered in domestic areas, as well as some Kharosthi inscriptions found on a few finds from tombs, Chinese characters and iconography would have been illegible to the local population, and therefore exotic (Selbitschka 2010:160-161; von Falkenhausen 1999:51-52). 
Considering Mary Helms' (1992:159-160, 1993:101-108, 173-191) claim that longdistance travelers who acquired the purported prestige goods were the sole keepers of their inherent cultural secrets begs the question: How exactly did the jin-silks get to the Tarim Basin? Were there specific journeymen who were able to decipher their iconography and inscriptions? Silk fabrics are commonly considered to have been the most important factor in so-called tributary trade. The assumption is that foreign parties such as the Tarim Basin polities submitted to Chinese suzerainty by delivering tribute to court. In return, they were lavishly rewarded with silk of various kinds (Yü 1967). A comprehensive analysis of Chinese diplomatic interactions with the Tarim Basin states between the first and fifth centuries C.E. has shown that there were next to no Chinese counter gifts of any significance. Jin and other silk fabrics were extended to political entities in what is now called Xinjiang in meaningful quantities on only four occasions. Moreover, none of these exchanges involved states associated with the four cemeteries under review here. The large numbers of imperial presents were either dowries in diplomatic marriages with local rulers or inauguration gifts when local rulers were incorporated into the Chinese bureaucratic system (Selbitschka 2015:98-104).

In contrast, tens of thousands of silk bales and especially jin-silk were given to nomad confederacies from the northern steppes such as the Xiongnu 匈奴 (Yü 1967:47). They, along with their almost equally mighty successors were powerful enough to extort huge numbers of Chinese "gifts" on a regular basis. Thus, it seems most likely that jin-silks, in particular, were traded by pastoralists as middlemen. Furthermore, there is little written evidence of actual silk trade between China and the Tarim Basin. The only piece I could find is a Kharosthi document that mentions Chinese merchants, who were expected to settle a tabby silk debt. It is clear that these traders came to the Tarim Basin and not the other way around. More significantly, they dealt with tabby weaves and not jin-silks (Burrow 1940:9, no. 35).

Even if jin-silks were not directly imported by the local population and no one really comprehended their iconography and inscriptions, they communicated ample symbolic capital to the outside world. In addition to high costs, technical complexity, exotic Chinese origin, and social restrictions, the immense relative value of these extraordinary textiles is beyond doubt. The only criteria that were not met were 6 and 7 , although one could argue that an item such as the arm guard from Niya tomb 95MN1M8 depicted in Fig. 2 (and comparable finds in 95MN1M3 and Yingpan tomb 95BYYM15) occupied special positions in the respective tomb assemblages. (This is a discussion for a separate article.) Suffice it so say that warp-faced compound tabby weaves were highly valuable. Elsewhere, my analysis revealed that only a minority of relatively wealthy Tarim Basin residents had access to them (Selbitschka 2010:153-158) (Tables 2, 3).

\section{The Responder's Point of View: Weft-Faced Compound Tabby Silk (Taqueté) as Copies of jin}

So far, there is no visible trace in the archaeological record that jin or any other kind of silk weave generated prestige, that is, an attitude of ansehen, among a set of like-minded individuals toward the owners of the silk. This is hardly surprising considering that no attention has been paid to the potential reactions of responders. Even if flamboyant and exotic silks were intended to gain the admiration of onlookers, assessing the high relative value of these artifacts does not offer any insights on whether such attempts were indeed successful. It is extremely difficult for archaeologists to reconstruct 
abstract value judgments of dead social actors. Nevertheless, I have developed a hypothesis by analogy with purported contemporary prestige goods. Like expensive sports cars, Rolex wrist watches are often referred to as modern-day prestige goods. The fact that certain clientele cannot resist buying cheap knock-offs while on vacation in some parts of the world suggests that they relate certain qualities to the ownership of the original model. To put it simply, by wearing fake Rolex watches, they pretend to be something they are not. If the proprietor of an original should be buried sporting his original watch, whereas some of his contemporaries were buried in the same cemetery wearing only replicas, then future generations of archaeologists would not be too far off in assuming that the latter aimed to present themselves as being in possession of the same esteemed traits as the owner of the authentic time piece. Most likely, such positive traits would be reduced to economic wealth, which, as the above discussion illustrated, is one of several possible aspects of genuinely generated prestige.

The Tarim Basin burials presented such fortunate circumstances. Polychrome patterned weft-faced compound tabby silk weaves (taqueté) were brought to light in twelve tombs at Yingpan and Zhagunluke (15.2\% of the total tombs) (Tables 2, 4). It has been convincingly argued that the weft-faced patterning technique originated in West Asia (Becker 1987:81-82; Emery 1980:8-13). This rather descriptive terminus technicus already hints at the most significant difference between polychrome patterned warp-faced compound tabbies (jin) and polychrome patterned weft-faced compound tabbies (taqueté). Both kinds of fabrics are based on a tabby weave that enhances the stability of the fabric structure. In taqueté cloth, the pattern is not achieved by overleaping warp threads but by overleaping weft threads. Owing to the inherent qualities of the silk thread, in particular its length and sturdiness, the technique of using warps to pattern a fabric was unique in China. Any other organic thread consists of rather short fibers that need to be spun into a longer thread. Such threads would have eventually torn under their own weight if arranged vertically as patterning warps on a loom for several meters. Silk threads consist of rather few individual fibers that are only slightly twisted; they can more easily withstand the strain of their own weight.

Looking at some of the Tarim Basin taqueté finds, it is easy to see that their iconography resembles Chinese warp-faced compound weaves. They depict wavelike mountainous landscapes as well as strange beasts and equestrians (Xinjiang Weiwu'er et al. 2003b:2-3; Wang 2005:104-105; see also the Yingpan finds below) (Figs. 4, 6). The most noteworthy details for the present discussion, however, are small, primarily orthogonal shapes that were positioned in front of or under the animals. Although rather crudely executed, they unmistakably imitate Chinese characters, one of the defining features of Chinese warp-faced weaves.

In the absence of evidence of weaving workshops at any of the Tarim Basin sites, there is no way of knowing whether these copies were produced on location or in West Asia as the weaving technique suggests. Perhaps the silk market in Sasanian Persia (224-651 C.E.) was more liberal than imperial Chinese officials when it came to polychrome patterned silk fabrics and offered cheaper merchandise than the steppe nomads. From a political point of view, it might indeed have been easier for the smaller states that are associated with the Yingpan and Zhagunluke cemeteries to access West Asian rather than Chinese merchandise. Unlike the states that were home of the Loulan and Niya sites, they barely figured at all in Chinese historiography. Whereas China's political relations with Loulan and Niya take up several pages in some early 


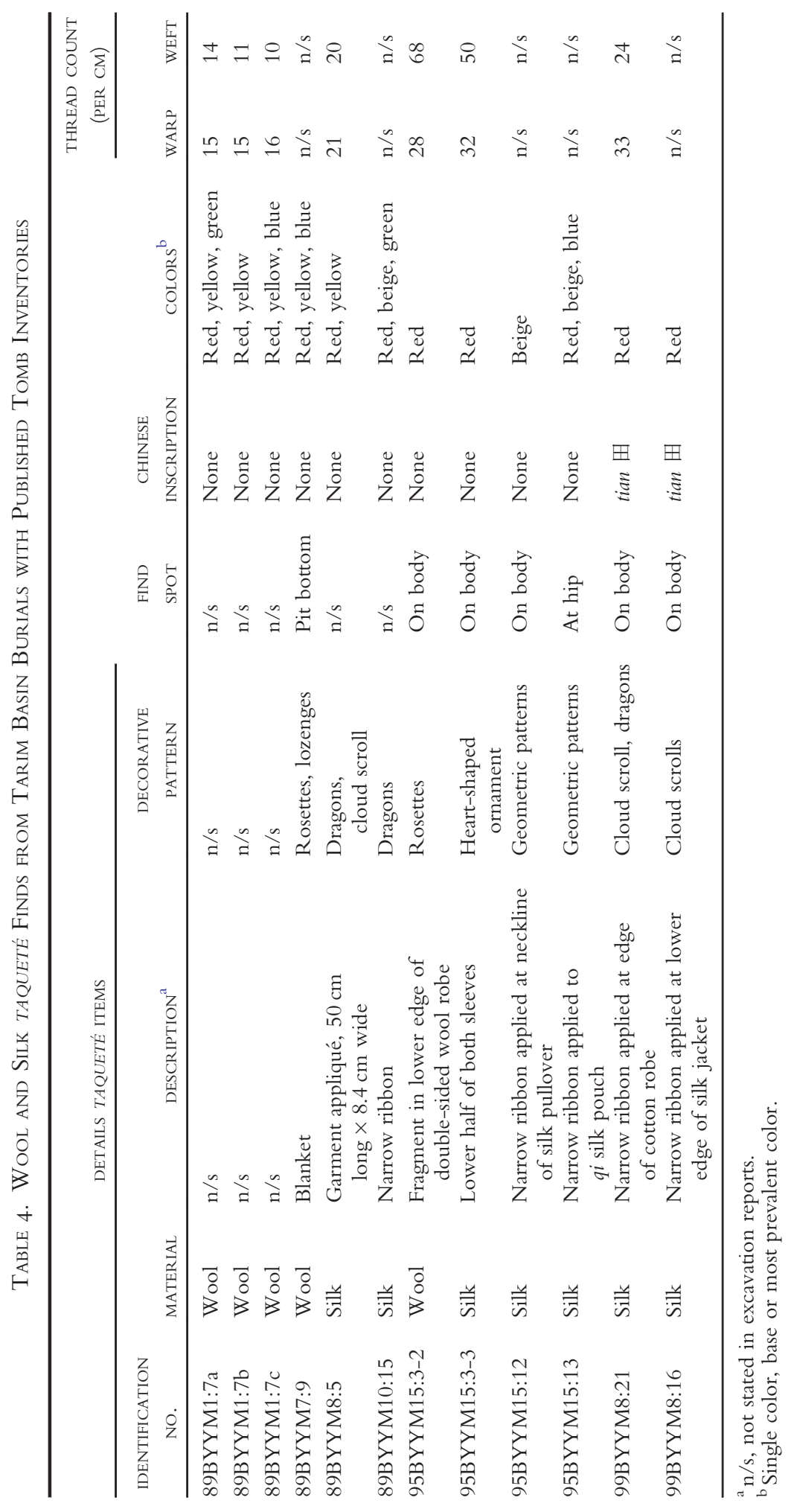




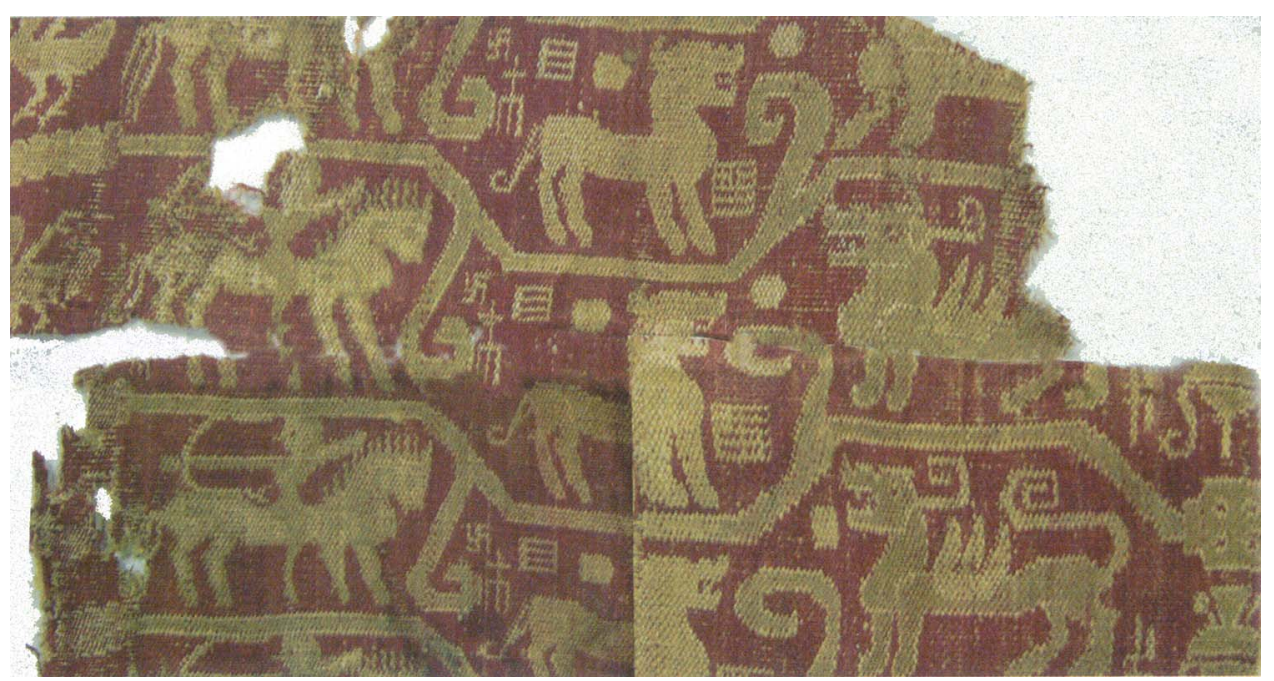

Fig. 4. Silken polychrome patterned weft-faced compound tabby weave (taqueté) imitating Chinese characters that was retrieved from Zhagunluke Tomb No. 98QZIM131 (after Zhao 2005a: color Plate 10.c).

standard histories, Yingpan and Zhagunluke were awarded no more than a few columns of text conveying only the most basic geographic and ethnographic data (Selbitschka 2010:56-57, 76-79, 87-88, 103-105).

At Yingpan, the weft-faced copies served the same purposes as their original counterparts, just as hypothetical Rolex emulations would on the wrists of their owners. Unfortunately, the data from Zhagunluke is too scanty to allow such conclusions. It is well attested that Chinese jin-silks as well as taqueté fabrics were interred with the deceased, but the evidence from the burials have not yet been released (Xinjiang Weiwu'er 2016:figs. 35, 65, 66, 68, 69, 73, 79). It is noteworthy, though, that larger pieces of taqueté cloth seem to have been attached at the edges of garments (Xinjiang Weiwu'er 2016:fig. 80). The fact that originals and copies were used similarly is illustrated by the grave goods in two contemporaneous graves at Yingpan. The occupant of tomb 95BYYM20 was wearing a robe whose edges were adorned by a narrow band of red Chinese jin-silk that bears the inscription deng gao 登高, “[May you] ascend [lofty] heights" (Xinjiang Wenwu 2002b:33; Zhao 2002:42-43) (Fig. 3, Table 3). Further details about this burial are unavailable as the jin-silk is the only find that has been published thus far. More is known about tomb 99BYYM8, which was occupied by an adult male and an adult female of unknown age. They were buried in a manner unique to Yingpan. The heads of both the man and woman were wrapped in floss silk cloths and both wore a headband cut from red tabby silk cloth and adorned with small round platelets made from either bronze (the man) or gold (the woman) leaf. Their chins were fastened by chin straps (mentonnière). The deceased man was dressed in a cotton robe to which a narrow red taqueté band had been applied at the long edge (Xinjiang Wenwu 2002a:67; Zhao 2002:58-59) (Figs. 1, 5, 6). The woman wore a tabby silk jacket adorned on the lower edge with the same silk taqueté as the man's robe.

It would be interesting to know whether such garments had been worn regularly by the man and woman or if they had been made exclusively for the funeral. As I 
mentioned above, this is a difficult question to answer. Figure 5 demonstrates that Tarim Basin cloth finds were not at all in pristine condition. Nevertheless, traces of mending and some signs of use on three items from Niya tomb 95MN1M3 indicate that at least some of the attire in the tomb was worn while the occupants were alive (Wang et al. 1999:101-105). Even if the clothes had been specifically tailored for display during the funerary rites, the effect of original and imitated fabrics would have been the same. The guests gathered at the tomb should see and admire certain skills that the occupants (or the bereaved) related with the original textiles.

It stands to reason that the valuable exotic Chinese originals - and by association certain of their owners' qualities irretraceable to us today-were highly admired by some members of ancient society, yet remained unattainable to them. Non-Chinese copies were meant to compensate for this perceived defect. There is a host of possible reasons why someone might not have been able to get their hands on specific objects: lack of financial means, social restrictions, or shortage in supply immediately come to mind. The important point, however, is to realize that certain social circles equated the possession of particular items with certain positive traits. Copies of the desirable warpfaced compound tabby weaves (jin) - a genuine prestige good in the context of the Tarim Basin tombs-were thought to identify their owners with these traits.

One might wonder how deeply the practice of emulation permeated the Tarim Basin societies. Given the poor condition and sometimes inadequate documentation of the sites, this is a difficult problem to tackle. Much of the information that might originally have been available has long since decayed or been stolen. Judging from the

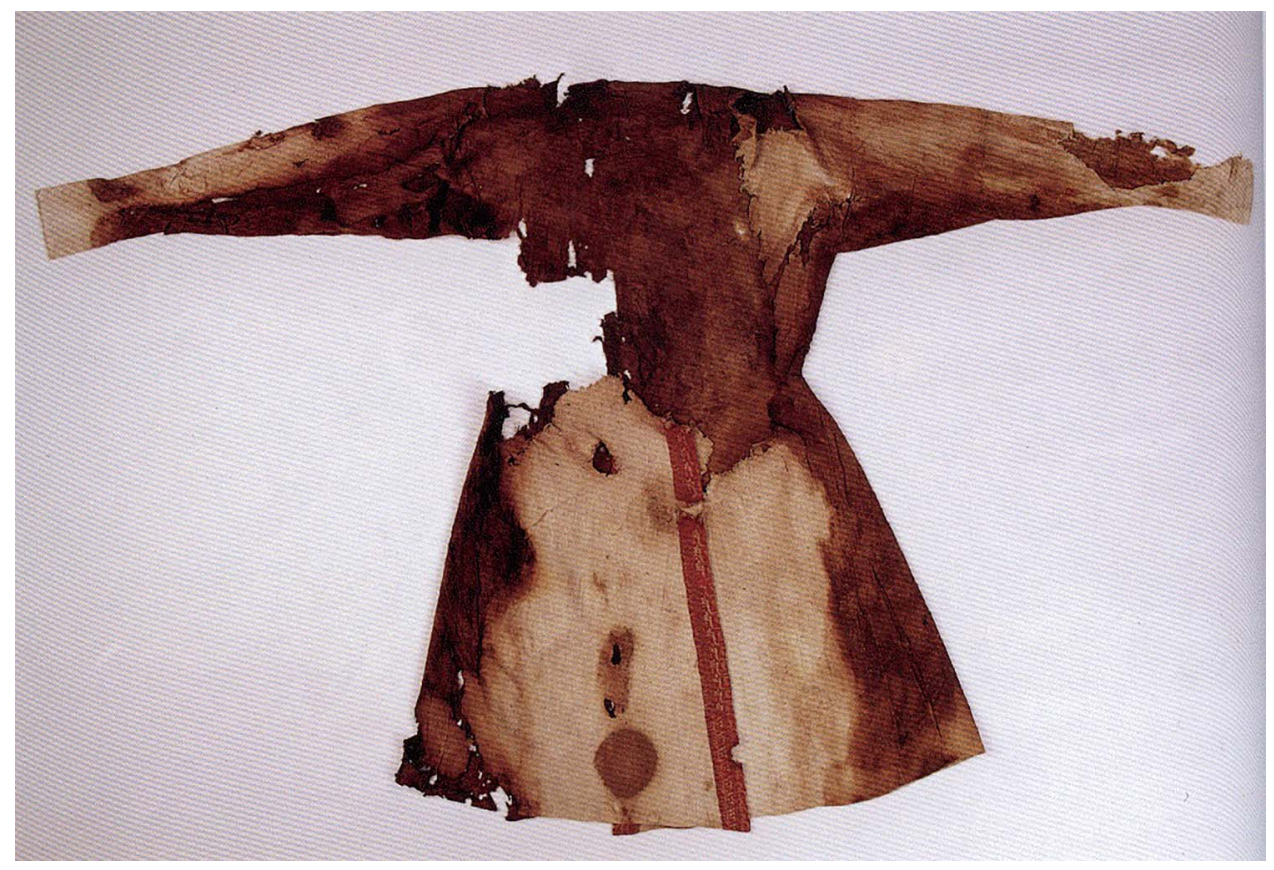

Fig. 5. Robe with taqueté ribbon embellishment on front edge, worn by male occupant of Tomb No. 99BYYM8 at Yingpan (after Zhao and Yu 2000:58, fig. 19). 


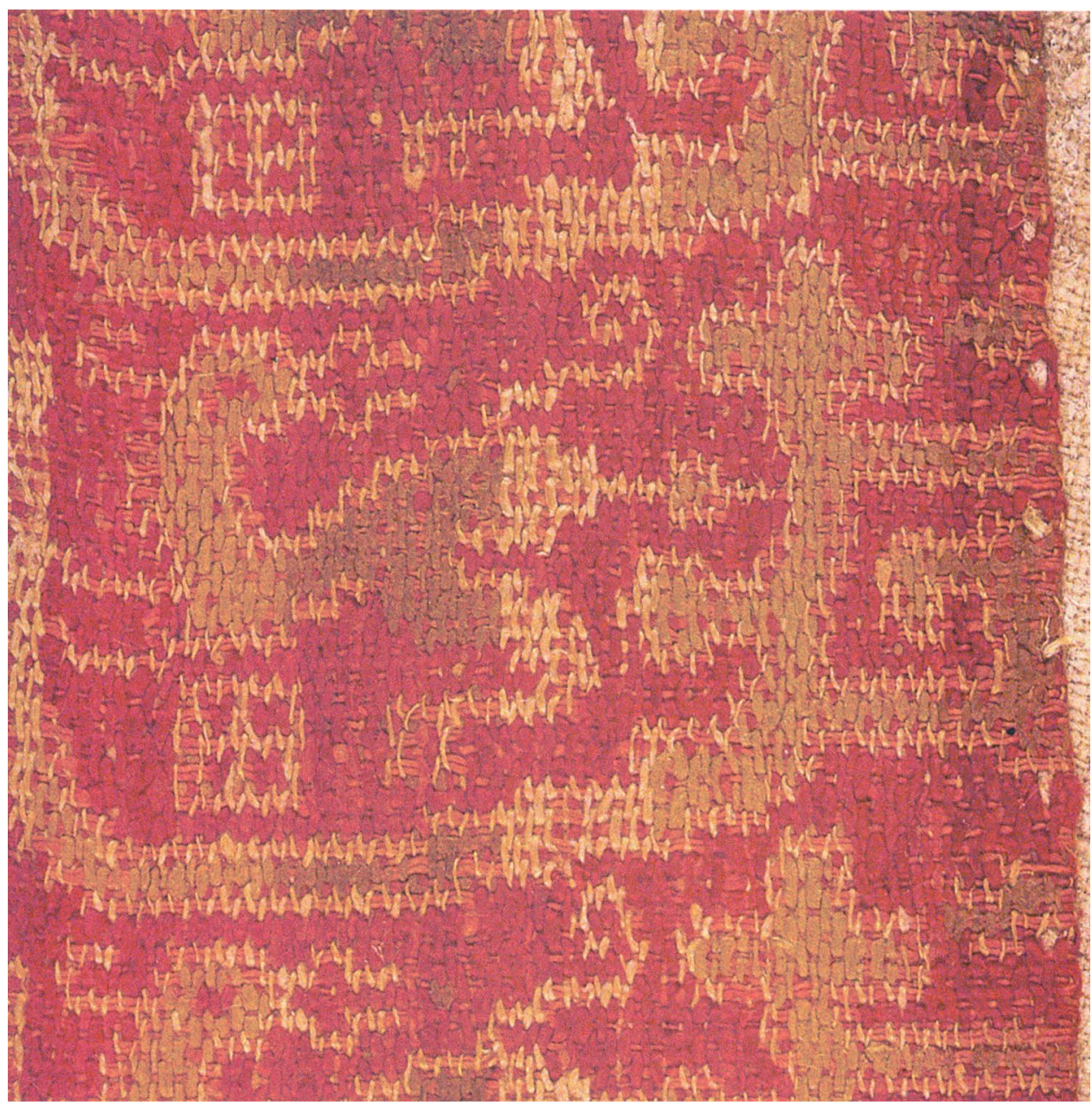

Fig. 6. Detail of taqueté fabric with imitation Chinese character tian $⿴ 囗 十$ [field] adorning robe of male occupant, Tomb No. 99BYYM8, Yingpan (after Zhao 2002:59, fig. 59.1).

material we actually have at our disposal, it seems emulation was not very widespread among the ancient Yingpan and Zhagunluke populations. The tomb assemblages that included taqueté silks usually comprised of high quality items. This suggests that even copies of jin-silks were not all that easy to acquire.

\section{EMULATION OF BYZANTINE SOLIDI IN NORTHERN CHINESE BURIALS}

Emulation on a much larger scale is visible in a number of northern Chinese tombs that date roughly from the early sixth to the mid-eighth century C.E. Table 5 summarizes all finds of Byzantine solidi and their copies in Chinese burials. Publications of these finds usually offer a little more information than whether the burials yielded either an original or a copy. ${ }^{5}$ 


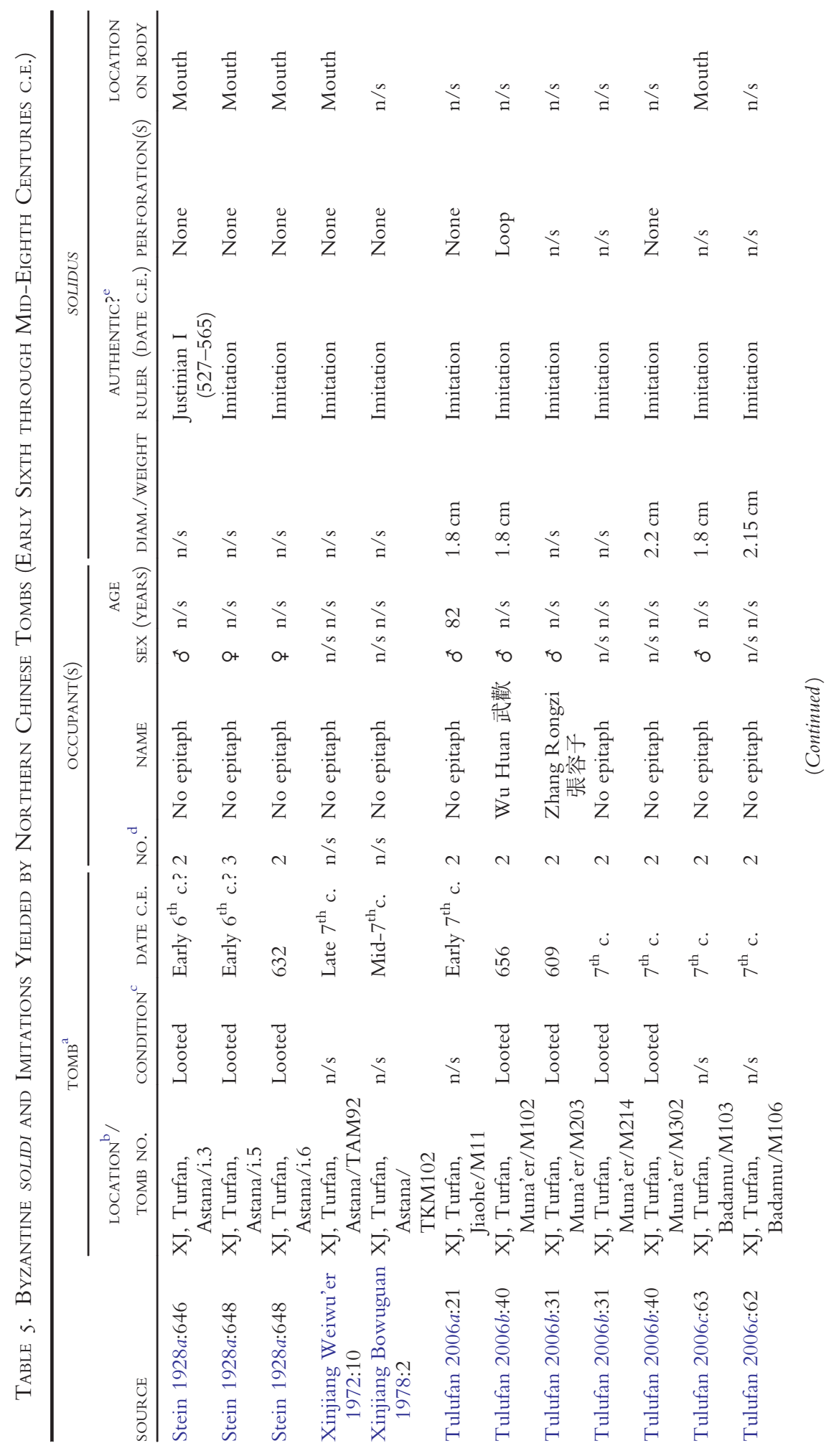




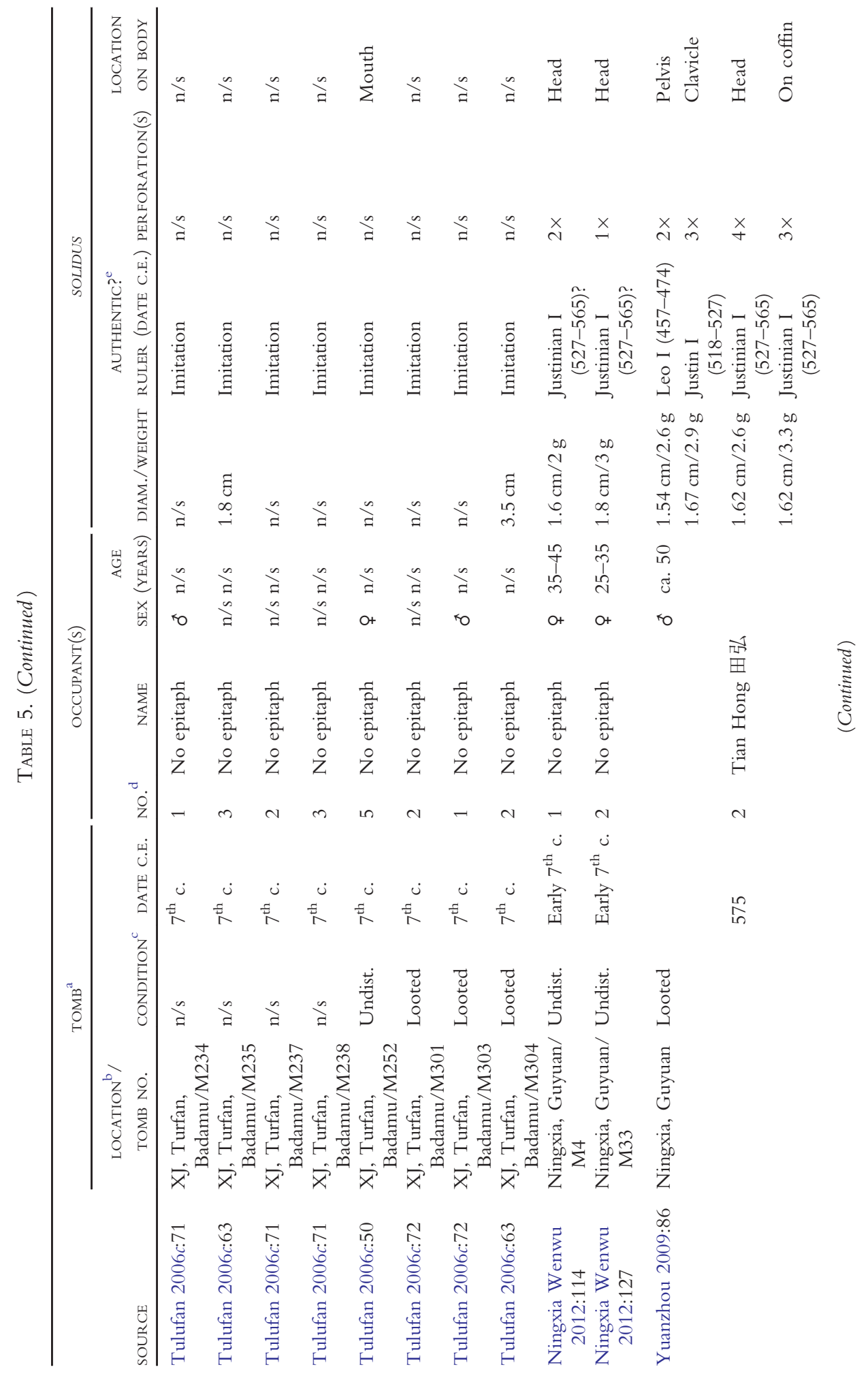




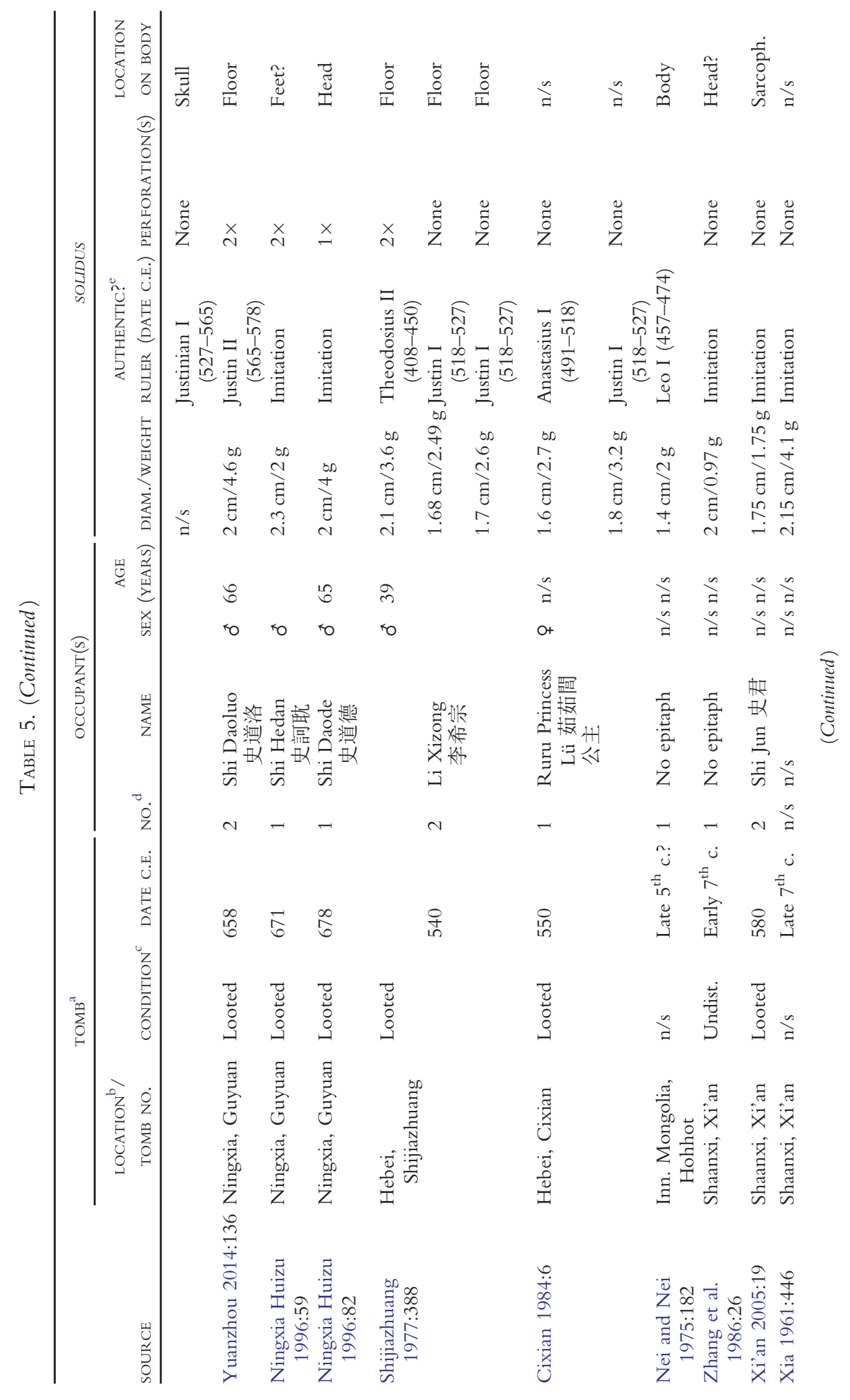




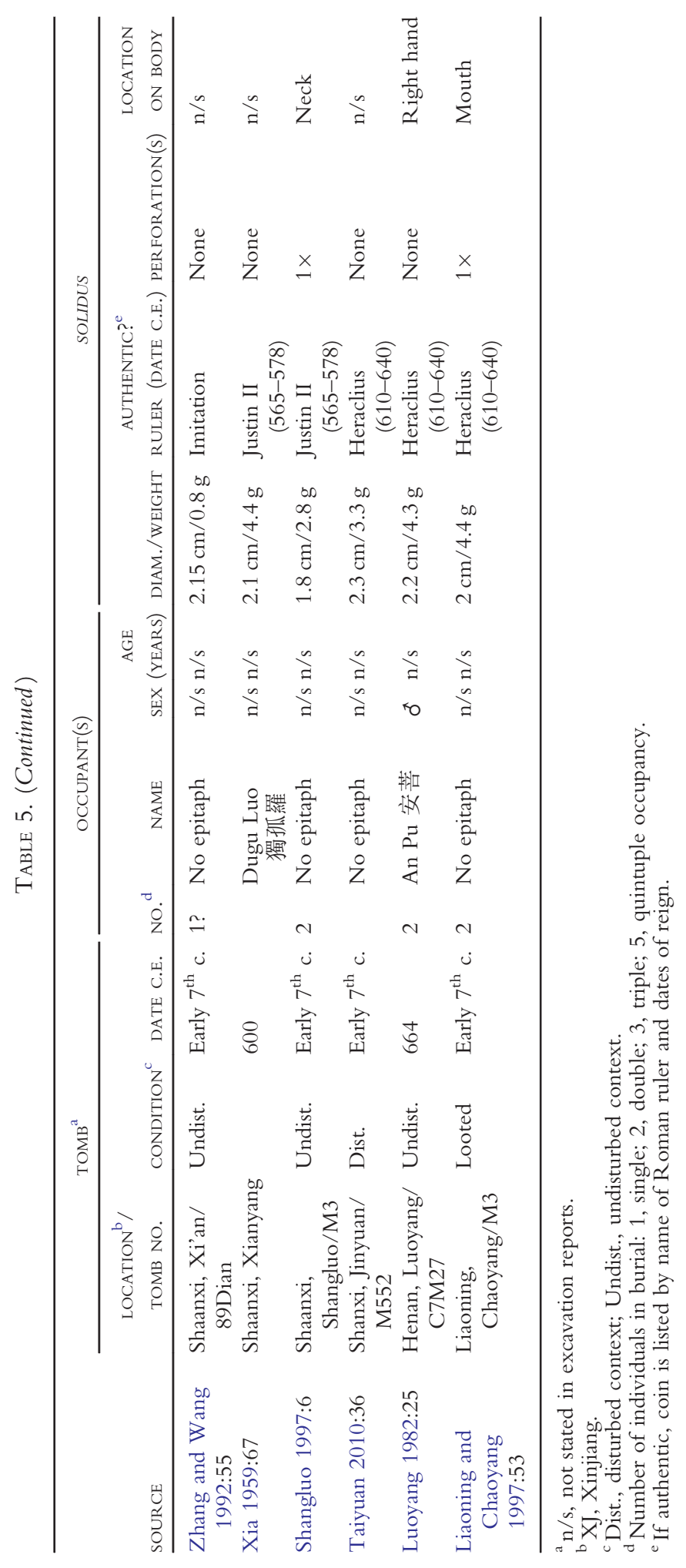


The relative value of Byzantine gold coins according to the criteria laid out above is quite high. Although they were small in size (usually no more than $2.3 \mathrm{~cm}$ in diameter and $4.6 \mathrm{~g}$ in weight), fairly easy to produce, and convenient to transport, they were not readily available in northern China, which corresponds to criterion 1. By the late third century C.E., gold as a raw material had become scant because of massive demand by Buddhist monasteries (criterion 2). The custom of gilding large-scale sculptures had all but exhausted domestic gold deposits and caused a tremendous price surge (Golas 1999:123).

The exotic nature of Eastern Roman gold coins is also beyond doubt (criterion 4). As early as the Western Han (206 B.C.E.-9 C.E.) period, China knew about the existence of the Western Roman Empire, but there is little evidence that the two realms were in direct contact with each other. Except for a doubtful mission from Marcus Aurelius (161-180 C.E.) to the Eastern Han (23-220 C.E.) in 166 C.E.- the visitor was probably a private merchant masquerading as an official envoy-and the establishment of a few embassies during the seventh century C.E., the Roman and Chinese courts remained distant from one another (Leslie and Gardiner 1996:161). The majority of exchanges between the Eastern Roman and Chinese cultural spheres were focused on commerce done in stages. It is highly unlikely that large numbers of Byzantine merchants ever set foot on Chinese ground or vice versa (Hansen 2012:82, 111). Thus, Eastern Roman artifacts remained rare and unusual sights in China (criterion 4b). As for the exotic character of the solidi as objects, they could hardly have been more different from traditional Chinese coins. While the former were minted in gold, the latter were cast in bronze. Moreover, from the early second century B.C.E. onwards, the obverse of so-called Chinese "cash" coins were dominated by two to four Chinese characters that either referred to the weight of the coin or the ushering in of a new era (Fig. 7), while the obverses of solidi showed the faces and names of the emperors under whose reign they were issued (Fig. 8). The image of a human being and Latin writing must have left an impression on Chinese observers who were only used to seeing Chinese graphs (criterion $4 \mathrm{a}$ ). The fact that most of the solidi and solidi copies also assumed special functions within tomb assemblages (criterion 6) and some were even heirlooms (criterion 7) is discussed below.

The mortuary data from northern China is fraught with problems. The majority of the tombs under review had been looted and the exact locations of many of the coins within the assemblages were not noted. Nonetheless, there is still some information to work with. For instance, by far the majority of finds come from the Turfan area in modern-day Xinjiang (Fig. 1). Of the 20 coins listed in Table 5, only one is an original Byzantine solidus; the remaining 19 finds were likely local copies. Similar to the jin-and taqueté silk applications on Yingpan (and perhaps Zhagunluke) clothes, emulation did not stop with the object itself. At Turfan, originals and copies were used in the same fashion. Both kinds of gold coins were found in the oral cavities of the occupants of roughly contemporary tombs. The little available evidence suggests that male deceased were given a slight preference over females in that more gold coins were found in men's mouths. Although not included in my list, many of the female occupants at Turfan were buried with a Sasanian silver drachm or, remarkably, a copy of the coin in their mouths (Skaff 1998:69). Whether the northwestern Chinese Byzantine gold or Sasanian silver coins might have had any relation with the ancient Mediterranean obolos custom is unclear at this point. A single coin was placed into the mouth of the deceased as payment to the ferryman Charon, who transported the souls of the dead across the 


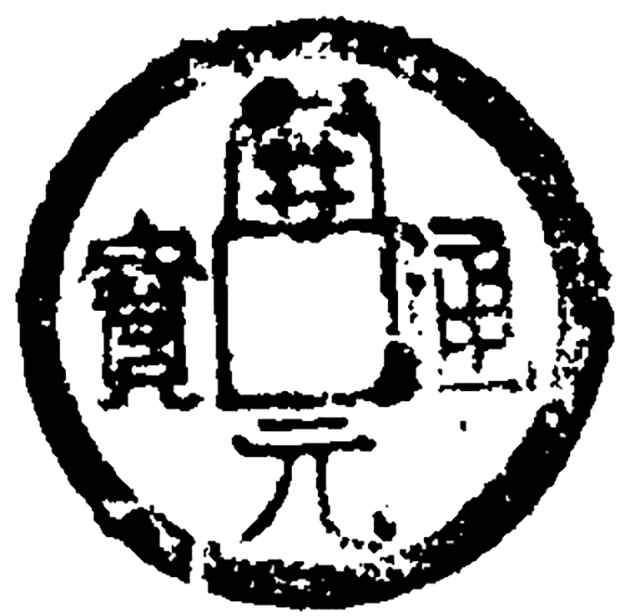

Fig. 7. Line drawing of a Kaiyuan tongbao 開元通寶 [“Circulating treasure (i.e., coin) marking beginning of new era”] coin, dated ca. 730 C.E. (after Taiyuan 2010:40, fig. 14).

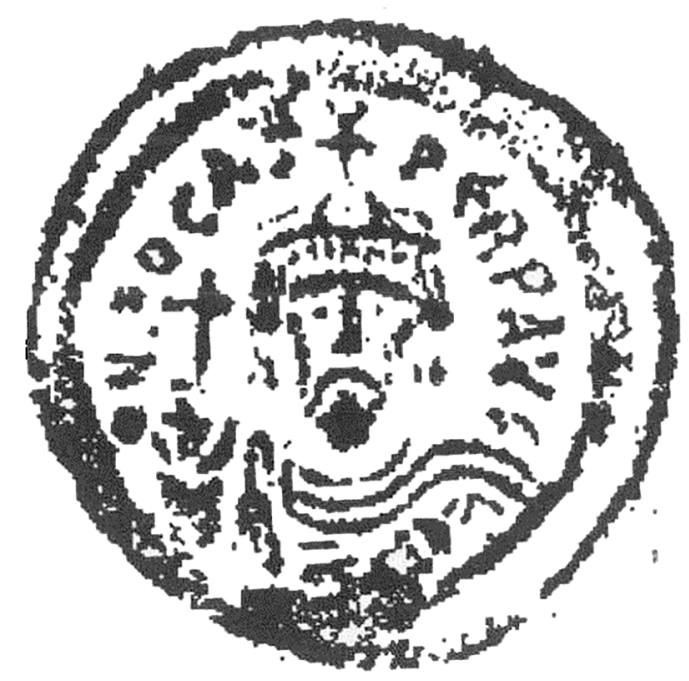

Fig. 8. Line drawing of solidus collected from field at Qingshui 清水, Gansu province; coin minted during the reign of Emperor Phocas (602-610 C.E.), inscribed "[OMINVS] N[OSTER] FOCAS PERP[ETVVS] AVG[VSTVS] [Our lord Phocas Eternal Augustus]" (after Yu 2006:74, fig. 2).

river Styx into the netherworld. We know that similar ideas indeed traveled from Classical antiquity as far as northern China because they were made visible by the chin straps that were recorded in some of the Yingpan tombs and other mainland Chinese burials (Müller 2006). Unfortunately, only one more instance of obolos (placing coins in mouths) is safely attested from Tomb No. 3 at Chaoyang 朝陽 in Liaoning province 
(Liaoning and Chaoyang 1997). Since there are no further finds in the area, it remains unknown whether the phenomenon was more widespread and if copies might have substituted for authentic solidi at other sites as well.

Although four out of six tombs at Guyuan 固原 in Ningxia province were looted, it appears as if solidi were used as part of a different custom there. The undisturbed burials of two single females yielded one original solidus each. Both solidi were found near the heads of the deceased and both exhibited at least one perforation. These small holes suggest that the coins were once attached to some kind of organic material, either sewn onto a cloth or suspended from some kind of thread. There is no way of knowing whether this was done when the deceased were still alive or was occasioned by the funeral. The respective finds from the remaining four burials suggest that the solidi and their copies were part of more or less intricate headdresses. The metalwork of the more elaborate pieces incorporated Sasanian iconography. This is not too surprising since epitaphs contained in some of the Guyuan tombs convey that the occupants at this particular cemetery were all members of the same family and traced their origins back to Sogdiana (a region in modern-day Tajikistan and Uzbekistan). The male occupants share the surname Shi 史, which was usually associated with the ancient city state of Kish (Skaff 2003:478-480). Despite being Chinese officials, the deceased seem to have retained their native religions. Once Zoroastrianism became the state religion in Sasanian Persia, it was soon adopted by the Sogdian city states. The Sasanian headdresses along with other Zoroastrian imagery in the tombs suggest that the solidi and their copies fulfilled a crucial role in some kind of religious practice. We cannot be sure what exact function the coins fulfilled, but it is obvious that they were vital to the process. However, solidi were foreign objects even back in Sogdiana and served no known purpose in Zoroastrian rituals hints at a more representational function of the coins in the context of elaborate golden headdresses. The prestige associated with the originals prompted the production of thinner and lighter copies.

The Guyuan finds are interesting for another reason. Their presence suggests that even members of the same family had difficulty getting their hands on originals. That this was not due to financial limitations is amply demonstrated by their rich graves. Many gold and silver objects remained in their tombs even after robbers had looted them. It seems as if genuine solidi were a rare commodity in sixth through mid-eighth century northern China, despite the fact that they were issued as currency in the western hemisphere of the early medieval world. Some of the authentic coins might very well have been heirlooms. For instance, Shi Daoluo's 史道洛 solidus was minted sometime during the reign of Justin II (565-578), but was not buried until 658 C.E. A similar situation occurred in Tian Hong's 田弘 tomb. The earliest of his five solidi dates over a century older than the burial itself. Of course it is possible that such pieces were acquired a couple of decades after they had been minted, but Tian Hong's coins suggest that a collection was accumulated over several generations.

The relative value of Byzantine solidi was certainly not nearly as high as that of Chinese jin-silks, but they were cherished enough that they were taken out of circulation by being buried at sites that stretched from the northwestern to the northeastern ends of mainland China. The high relative value and rarity of Byzantine solidi is also confirmed by the fact that only one was stashed in the famous Hejiacun 何家村 hoard in Xi'an, which comprised over 220 silver and gold objects in addition to silver ingots, drinking vessels and belts made from glass, rock crystal, and jade, as well as rubies, sapphires, and amber 
(Hansen 2003:15). More importantly, at almost all known stations of their journey to the east, solidi were associated with enough prestige to warrant emulation.

\section{CONCLUSION}

The preceding discussion has demonstrated that prestige as a social force is not equivalent to social status, even though past studies have mostly treated it thusly. This has significant ramifications for using the concept of prestige goods as an analytical category. Previous scholarship has mainly concentrated on proving that pre-historic societies had developed hierarchical structures. Prestige goods are considered active forces that shaped the structure of ancient societies; indeed, they may very well have been intended as such. However, prestige, like any social phenomenon, is not simply a unilateral tool employed by the powerful and wealthy. If prestige is defined as Ansehen or esteem, it demands that we take its actual effect on recipients seriously. So-called prestige goods only imparted prestige to their owners when onlookers truly admired the owners for their command of certain objects. Consequently, spotting genuine prestige goods in archaeological contexts is less about identifying dominant power structures and more about exposing the intricate workings of society as a whole.

With the publication of Thorstein Veblen's seminal study The Theory of the Leisure Class, emulation as a strategy for blurring and overcoming social boundaries attained a prominent role in the discussion of social hierarchy (Miller 1987:136). Many scholars linked emulation with status, which in turn was equated with prestige. A more nuanced approach towards prestige and emulation as suggested here facilitates a deeper comprehension of ancient social and cultural practices. Shifting focus from signalers to responding parties demonstrates that the act of emulation was likely not simply a manifestation of the efforts of eager upstarts attempting to improve their own social standing. It enables us to entertain the idea that people in the Central Asian Tarim Basin and even on the eastern margins of the Roman Empire-since Chinese jin-silks traveled at least as far as Palmyra (Schmidt-Colinet et al. 2000; Stauffer 1996; von Falkenhausen 1999:44-52, 2000)—appreciated these magnificent textiles for more than their apparent exoticism and costs. These were the most flamboyant and technically complicated fabrics available at the time, a fact that surely did not go unnoticed by potential consumers. The common way of denoting prestige objects chiefly by virtue of cost or rarity (i.e., high relative value) can only be a first step in the analytical process. Admittedly, archaeologists seldom have more evidence to work with other than that indicating cost, exclusiveness, or exotic character of artifacts, so written records might augment some of the conclusions based on archaeological evidence. However, detecting instances of contemporary emulation in close geographic proximity and use with the original object makes it possible in some cases to take the second necessary step of distinguishing genuine prestige goods from mere status symbols or luxury goods. The prestige associated with such artifacts was a decisive factor for acquiring or producing copies. It is important to understand that the act of emulation always is an expression of the ansehen that is awarded to a person or an object. To put it simply, if someone did not like what they saw, they would not have bothered copying it. Applying such rigorous standards to one's archaeological material means that we have at least one convincing method at our disposal for identifying genuine prestige goods in mortuary settings. 


\section{ACKNOWLEDGMENTS}

I am grateful to Rowan Flad, Mike Carson, Jaida Samudra, Duane Joseph Corpis, John Kieschnick, and the anonymous Asian Perspectives reviewers for their valuable comments on this article; they are deeply appreciated. Any remaining mistakes or shortcomings are, of course, my own responsibility.

\section{NOTES}

1. For Loulan, see Bergman (1939:118, 128-134, 140-142); Hedin (1937:6, 90-97, 132); Stein (1928a:225-230); Sylwan (1949:36-49); and Xinjiang Loulan (1988:23-39). For Yingpan, see Stein (1928b:755-761) and Xinjiang Wenwu (1994, 1999a, 2001, 2002a, 2002b). For Zhagunluke, see Xinjiang Weiwu'er et al. (2003a, 2003b) and Zhongguo and Xinjiang (1997). For Niya, see Wang and colleagues (1999) and Xinjiang Wenwu (1998, 1999b, 1999c, 2000).

2. For technical aspects of different silk weaves, see Becker (1987:83-87) and Emery (1980:76-78, 133-136, 140-144).

3. The document numbers in these citations refer to inscribed wooden tablets or slips that were found at Niya and in the Lopnor region.

4. For a description of looms of that era, see Becker (1987:1); Kuhn (1995:78); and Zhao (2005b:96-107). For a recent discovery of models of silk looms, see Chengdu and Jingzhou (2014).

5. For a slightly outdated list of coins and provenance, see Thierry and Morrisson (1994).

\section{REFERENCES CITED}

Ames, Kenneth M.

2008 The archaeology of rank, in Handbook of Archaeological Theories: 487-513, ed. R. Alexander Bentley, Herbert D. G. Maschner, and Christopher Chippindale. Lanham, NY: AltaMira Press.

Anheier, Helmut K., Jürgen Gerhards, and Frank P. Romo

1995 Forms of capital and social structure in cultural fields: Examining Bourdieu's social topography. American Journal of Sociology 100(4):859-903.

Appadurai, Arjun

1986 Introduction: Commodities and the politics of value, in The Social Life of Things: Commodities in a Cultural Perspective: 3-63, ed. Arjun Appadurai. Cambridge: Cambridge University Press.

Bagley, Jennifer M., and Robert Schumann

2013 Materialized prestige: Remarks on the archaeological research of social distinction based on case studies of the late Hallstatt golden necklaces and early La Tène Maskenfibeln, in Interpretierte Eisenzeiten: Fallstudien, Methoden, Theorie. Tagungsbeiträge der 5. Linzer Gespräche zur interpretativen Eisenzeitarchäologie [Iron Ages Interpreted: Case Studies, Methods, Theories. Papers Presented at the 5th Linzer Discussions on Interpretative Iron Age Archaeology]: 123-136, ed. Raimund Karl and Jutta Leskovar. Linz: Oberösterreichisches Landesmuseum.

Bagwell, Laurie Simon, and B. Douglas Bernheim

1996 Veblen effects in a theory of conspicuous consumption. The American Economic Review 86(3):349-373.

Barkow, Jerome H.

1975 Prestige and culture: A biosocial interpretation. Current Anthropology 16(4):553-572.

BECKER, JOHN

1987 Pattern and Loom: A Practical Study of the Development of Weaving Techniques in China, Western Asia and Europe. Copenhagen: Rhodos International Publishers.

Bergman, Folke

1939 Archaeological Researches in Sinkiang: Especially the Lop-nor Region. Reports from the Scientific Expedition to the North-Western Provinces of China under the Leadership of Dr. Sven Hedin: The Sino-Swedish Expedition Publication 7, part 7, Archaeology 1. Stockholm: Bokförlags Aktiebolaget Thule. 
BINFORD, LEWIS R.

1971 Mortuary practices: Their study and potential. Memoirs of the Society for American Archaeology 25:6-29.

Bliege Bird, Rebecca, and Eric Alden Smith

2005 Signaling theory, strategic interaction, and symbolic capital. Current Anthropology 46(2):221-248.

Boudon, Raymond, and Francois Bourricaud

1992 Soziologische Stichworte: Ein Handbuch [Sociological Keywords: A Handbook]. Opladen: Westdeutscher Verlag.

Bourdieu, Pierre

1977 Outline of a Theory of Practice. Cambridge: Cambridge University Press.

1986 The forms of capital, in Handbook of Theory and Research for the Sociology of Education: 241-258, ed. John G. Richardson. New York: Greenwood.

1989 Social space and symbolic power. Sociological Theory 7(1):14-25.

1990 The Logic of Practice. Stanford: Stanford University Press.

Boyd, Robert, and Peter J. Richerson

1985 Culture and the Evolutionary Process. Chicago and London: The University of Chicago Press.

1996 Why culture is common, but cultural evolution is rare. Proceedings of the British Academy 88:77-93.

Brumfiel, Elizabeth M., and Timothy K. Earle

1987 Specialization, exchange and complex societies: An introduction, in Specialization, Exchange and Complex Societies: 1-9 ed. Elizabeth M. Brumfiel and Timothy K. Earle. Cambridge: Cambridge University Press.

Bunker, Emma C.

2001 The cemetery at Shanpula, Xinjiang: Simple burials, complex textiles, in Fabulous Creatures from the Desert Sands: Central Asian Woolen Textiles from the Second Century BC to the Second Century AD: 15-45, ed. Dominik Keller and Regula Schorta. Riggisberg: AbeggStiftung.

Burrow, ThOMAS

1940 A Translation of the Kharosthi Documents from Chinese Turkestan. London: Royal Asiatic Society.

Campbell, Colin

1995 Conspicuous confusion? A critique of Veblen's Theory of Conspicuous Consumption. Sociological Theory 13(1):37-47.

Champion, SARA

1982 Exchange and ranking: The case of coral, in Ranking, Resource and Exchange: Aspects of the Archaeology of Early European Society: 67-72, ed. Colin Renfrew and Stephen Shennan. Cambridge: Cambridge University Press.

Chapman, John, Tom Higham, Vladimir Slavchev, Bisserka Gaydarska, and Noah Honch

2006 The social context of the emergence, development and abandonment of the Varna cemetery, Bulgaria. European Journal of Archaeology 9(2-3):159-183.

Chengdu Wenwu Kaogu Yanjiusuo 成都文物考古研究所 ANd JingZhou Wenwu Baohu ZhongXin 荊州文物保護中心

2014 Chengdu shi Tianhuizhen Laoguanshan Han mu 成都市天回鎮老官山漢墓 [A Han period tomb at Laoguanshan near the Tianhui hamlet in Chengdu]. Kaogu 考古 7:59-70.

Cixian Wenhuaguan 磁縣文化館

1984 Hebei Cixian Dong Wei Ruru gongzhu mu fajue jianbao 河北磁縣東魏茹茹公主墓發掘簡報 [Preliminary excavation report on the tomb of an Eastern Wei Ruru princess at Cixian, Hebei province]. Wenwu 文物 4:1-9.

Clark, John E., and Michael Blake

1994 The power of prestige: Competitive generosity and the emergence of rank societies in lowland Mesoamerica, in Factional Competition and Political Development in the New World: 17-30, ed. E. Brumfiel and J. Fox. Cambridge: Cambridge University Press.

Coleman, James S.

1988 Social capital in the creation of human capital. American Journal of Sociology 94:95-120. 
Costin, Cathy Lynne

1991 Craft specialization: Issues in defining, documenting, and explaining the organization of production. Archaeological Method and Theory 3:1-57.

DeMarrais, Elizabeth

2011 Figuring the Group. Cambridge Archaeological Journal 21(2):165-186.

Dietler, Michael

2010 Consumption, in The Oxford Handbook of Material Culture: 209-228, ed. Dan Hicks and Mary C. Beaudry. Oxford: Oxford University Press.

2011 Feasting and fasting, in The Oxford Handbook of the Archaeology of Ritual and Religion: 179-194, ed. Timothy Insoll. Oxford: Oxford University Press.

Durlauf, Steven N., and Marcel Fafchamps

2005 Social capital, in Handbook of Economic Growth, vol. 1B: 1639-1699, ed. Philippe Aghion and Steven N. Durlauf. Amsterdam: Elsevier.

Eggert, Manfred K. H.

1991 Prestigegüter und Sozialstruktur in der Späthallstattzeit: Eine kulturanthropologische Perspektive [Prestige goods and social structure in the Late Hallstatt period: A cultural anthropological perspective]. Saeculum 42:1-28.

EMERy, Irene

1980 The Primary Structure of Fabrics: An Illustrated Classification. Washington, D.C.: Textile Museum.

FLAD, ROWAN

2000 Ritual or structure? Analysis of burial elaboration at Dadianzi, Inner Mongolia. Journal of East Asian Archaeology 3(3-4):1-29.

2007 Rethinking the context of production through an archaeological study of ancient salt production in the Sichuan Basin, China. Archaeological Papers of the American Anthropological Association 17(1):108-128.

2011 Salt Production and Social Hierarchy in Ancient China: An Archaeological Investigation of Specialization in China's Three Gorges. Cambridge: Cambridge University Press.

2012 Bronze, jade, gold, and ivory: Valuable objects in ancient Sichuan, in The Construction of Value in the Ancient World: 306-335, ed. John K. Papadopoulos and Gary Urton. Los Angeles: Cotsen Institute of Archaeology, University of California at Los Angeles.

Flad, Rowan, and Zachary X. Hruby

2007 'Specialized' production in archaeological contexts: Rethinking specialization, the social value of products, and the practice of production. Archaeological Papers of the American Anthropological Association 17(1):1-19.

Fogelin, Lars, and Michael Brian Schiffer

2015 Rites of passage and other rituals in the life histories of objects. Cambridge Archaeological Journal 25(4):815-827.

Foladare, Irving S.

1969 A clarification of 'ascribed status' and 'achieved status.' The Sociological Quarterly 10(1):53-61.

Frankenstein, Susan, and Michael Rowlands

1978 The internal structure and regional context of early Iron Age society in south-western Germany. Bulletin of the Institute of Archaeology, University College London 15:73-112.

FREEMAN, LinTON C.

1992 The sociological concept of "group": An empirical test of two models. American Journal of Sociology 98(1):152-166.

Friedman, Jonathan, and Michael Rowlands

1977 Notes towards an epigenetic model of the evolution of 'civilisation,' in The Evolution of Social Systems: Proceedings of a Meeting of the Research Seminar in Archaeology and Related Subjects, Held at the Institute of Archaeology, London University: 201-276, ed. J. Friedman and M. Rowlands. London: Gerald Duckworth \& Co.

Golas, Peter J.

1999 Science and Civilisation in China, Vol. 5: Chemistry and Chemical Technology, Part 13: Mining. Cambridge: Cambridge University Press. 
Goode, William J.

1978 The Celebration of Heroes: Prestige as a Social Control System. Berkeley: University of California Press.

Gosden, Chris

1987 Debt, production, and prehistory. Journal of Anthropological Archaeology 8:355-387.

Gosden, Chris, and Yvonne Marshall

1999 The cultural biography of objects. World Archaeology 31(2):169-178.

GOUld, Roger V.

2002 The origins of status hierarchies: A formal theory and empirical test. American Journal of Sociology 107(5):1143-1178.

Graeber, DAVID

2011 Consumption. Current Anthropology 52(4):489-511.

HANSEn, VALERIE

2003 The Hejia village hoard: A snapshot of China's Silk Road trade. Orientations 43(2):14-19.

2012 The Silk Road: A New History. Oxford: Oxford University Press.

HANSHU

1962 Ban Gu. Hanshu. Beijing: Zhonghua Shuju.

Haselgrove, Colin

1982 Wealth, prestige and power: The dynamics of late Iron Age political centralization in southeast England, in Ranking, Resource and Exchange: Aspects of the Archaeology of Early European Society: 79-88, ed. Colin Renfrew and Stephen Shennan. Cambridge: Cambridge University Press.

HAYDEN, BRIAN

1998 Practical and prestige technologies: The evolution of material systems. Journal of Archaeological Method and Theory 5(1):1-55.

2009 Funerals as feasts: Why are they so important? Cambridge Archaeological Journal 19(1):29-52.

Hedin, Sven Anders

1937 Der wandernde See [The Wandering Lake]. Leipzig: F.U. Brockhaus.

Helms, Mary W.

1992 Long-distance contacts, elite aspirations, and the age of discovery in cosmological context, in Resources, Power, and Interregional Interaction: 157-174, ed. Edward M. Schortman and Patricia A. Urban. New York: Plenum Press.

1993 Craft and the Kingly Ideal: Art, Trade, and Power. Austin: University of Texas Press.

Henrich, Joseph, and Francisco J. Gil-White

2001 The evolution of prestige: Freely conferred deference as a mechanism for enhancing the benefits of cultural transmission. Evolution and Human Behavior 22:165-196.

Higham, Tom, John Chapman, Vladimir Slavchev, Bisserka Gaydarska, Noah Honch, Yordan Yordanov, AND BRANimira Dimitrova

2007 New perspectives on the Varna cemetery (Bulgaria): AMS dates and social implications. Antiquity 81:640-654.

Homans, George C.

1950 The Human Group. New York: Harcourt, Brace \& Company.

1974 Social Behavior: Its Elementary Forms. New York: Harcourt Brace Jovanovich.

1980 Prestige or status? Contemporary Sociology 9(2):178-180.

JUNKer, LAura LeE

1993 Craft goods specialization and prestige goods exchange in Philippine chiefdoms of the fifteenth and sixteenth centuries. Asian Perspectives 32(1):1-35.

Kim, JangsuK

2001 Elite strategies and the spread of technological innovation: The spread of iron in the Bronze Age societies of Denmark and southern Korea. Journal of Anthropological Archaeology 20:442-478. 
KIm, SeUng-OG

1994 Burials, pigs, and political prestige in Neolithic China. Current Anthropology 35(4):119-141.

KopytofF, IGOR

1986 The cultural biography of things: Commoditization as process, in The Social Life of Things: Commodities in a Cultural Perspective: 64-91, ed. Arjun Appadurai. Cambridge: Cambridge University Press.

Kristiansen, Kristian

1987 Center and periphery in Bronze Age Scandinavia, in Center and Periphery in the Ancient World: 74-85, ed. Michael Rowlands, Mogens Larsen, and Kristian Kristiansen. Cambridge: Cambridge University Press.

2012 Decentralized complexity: The case of Bronze Age northern Europe, in Pathways to Power: New Perspectives on the Emergence of Social Inequality: 169-192, ed. T. Douglas Price and Gary M. Feinman. New York: Springer.

Kuhn, Dieter

1995 Silk weaving in ancient China: From geometric figures to patterns of pictorial Likeness. Chinese Science 12:77-114.

Larivée, Serge, Carole Sénéchal, and Geneviève Chénard

2013 Les côtés ténébreux de Mère Teresa [The dark sides of Mother Teresa]. Studies in Religion/ Sciences Religieuses 42(3):319-345.

Leslie, D. D., ANd K.H.J. Gardiner

1996 The Roman Empire in Chinese Sources. Roma: Bardi Editore.

LI, JIAN

2003 The Glory of the Silk Road: Art from Ancient China. Dayton: The Dayton Art Institute.

LiaOning SHENG Wenwu KaOgu YanjIUSUO 遼寧省文物考古研究所 AND ChaOyang SHi BowUGUAN 朝陽市博物館

1997 Chaoyang Shuangtaqu Tang mu 朝陽雙塔區唐墓 [A Tang period tomb in the Shuangta district of Chaoyang]. Wenwu 文物 11:51-56

LIN, NAN

1999 Building a network theory of social capital. Connections 22(1):28-51.

2001 Social Capital: A Theory of Social Structure and Action. Cambridge: Cambridge University Press.

LiNTON, RALPH

1936 The Study of Man: An Introduction. New York: Appleton-Century-Crofts.

LiNYI SHI BOwUGUAN 臨沂市博物館

1984 Shandong Linyi Jinqueshan Zhou shi muqun fajue jianbao 山東臨沂金雀山周氏墓群發 掘簡報 [Preliminary report on the Zhou family cemetery at Jinqueshan in Linyi (County), Shandong]. Wenwu 文物 11:41-58.

LiU Hexin 劉合心

2006 Handai taolian wenshi duoying 漢代陶嵒紋飾捜英 [Discussion of decorative patterns on circular ceramic boxes from the Han period]. Wenbo 文博 2:34-40.

LIU, LI

2003 'The Products of minds as well as of hands': Production of prestige goods in the Neolithic and early state periods of China. Asian Perspectives 42(1):1-40.

LIU, XINRU

2010 The Silk Road in World History. Oxford: Oxford University Press.

LUOYANG SHI WENWU GONGZUODUI 洛陽市文物工作隊

1982 Luoyang Longmen Tang An Pu fufu mu 洛陽龍門唐安菩夫婦墓 [The Tang period joint burial of $\mathrm{An} \mathrm{Pu}$ (and his wife) at Longmen near Luoyang]. Zhongyuan wenwu 中原文物 $3: 21-27$.

MaUSS, Marcel

1923-1924 Essai sur le don: Forme et raison de l'échange dans les sociétiés archaïques [The gift: Forms and functions of exchange in ancient societies]. L'Année sociologique, nouvelle série 1:30-186.

1966 The Gift: Forms and Functions of Exchange in Ancient Societies. London: Cohen \& West. 
Miller, Daniel

1987 Material Culture and Mass Consumption. Oxford, New York: Basil Blackwell.

Mizoguchi, Koji

2013 The evolution of prestige good systems: An application of network analysis to the transformation of communication systems and their media, in Network Analysis in Archaeology: New Approaches to Regional Interaction: 151-178, ed. Karl Knappett. Oxford: Oxford University Press.

Mokken, Robert J.

1979 Cliques, clubs and clans. Quality and Quantity 13:161-173.

MOODy, James

2001 Peer influence groups: Identifying dense clusters in large networks. Social Networks 23:261-283.

MORRIS, IAN

1992 Death-Ritual and Social Structure in Classical Antiquity. Cambridge: Cambridge University Press.

Mullins, Paul R.

2004 Ideology, power, and capitalism: The historical archaeology of consumption, in A Companion to Social Archaeology: 195-211, ed. Lynn Meskell and Robert W. Preucel. Oxford: Blackwell Publishing.

2011 The archaeology of consumption. Annual Review of Anthropology 40:133-144.

MÜller, SHING

2006 Chin-straps of the early Northern Wei: New perspectives on the trans-Asiatic diffusion of funerary practices. Journal of East Asian Archaeology 5(1-4):28-71.

Nei MengGu Wenwu GongZuo dui 內蒙古文物工作隊 And Nei MengGu Bowuguan 內蒙古博物館 1975 Huhehaote shi fujin chutu de waiguo jin yin bi 呼和浩特市附近出土的外國金銀幣 [Foreign gold and silver coins excavated in the vicinity of Huhehaote]. Kaogu 考古 3:182-185.

NingXia Huizu Zizhiqu Guyuan Bowwuguan 寧夏回族自治區固原博物館

1996 Guyuan nanjiao Sui Tang mudi 固原南郊隋唐墓地 [A Sui and Tang period cemetery in the southern suburbs of Guyuan]. Beijing 北京: Wenwu chubanshe 文物出版社.

NingXIA WeNwU KaOGU YanjIUSUO 寧夏文物考古研究所

2012 Guyuan Jiulongshan Han Tang muzang 固原九龍山漢唐墓葬 [Tombs of the Han and Tang periods at Jiulongshan, Guyuan city (Ningxia province)]. Beijing 北京: Kexue chubanshe 科學出版社.

O'SHEA, JOHN M.

1984 Mortuary Variability: An Archaeological Investigation. Orlando, FL: Academic Press.

OSTROM, ELINOR

2000 Social capital: A fad or fundamental concept? in Social Capital: A Multifaceted Perspective: 172-214, ed. Partha Dasgupta and Ismail Seragilden. Washington, D.C.: World Bank.

Papadopoulos, John K., and Gary Urton

2012 The Construction of Value in the Ancient World. Los Angeles: Cotsen Institute of Archaeology, University of California at Los Angeles.

Parker Pearson, Mike

2000 The Archaeology of Death and Burial. Phoenix: Texas A\&M University Press.

Peebles, Christopher S., and Susan M. Kus

1977 Some archaeological correlates of ranked societies. American Antiquity 42(3):421-448.

Peregrine, Peter N.

1991 a Some political aspects of craft specialization. World Archaeology 23(1):1-11.

$1991 b$ Prehistoric chiefdoms on the American midcontinent: A world-system based on prestige goods, in Core/Periphery Relations in Precapitalist Worlds: 193-211, ed. Christopher Chase-Dunn and Thomas D. Hall. Boulder, CO: Westview Press.

1992 Mississippian Evolution: A World-System Perspective. Madison, WI: Prehistory Press.

1996 Archaeology and world systems theory. Sociological Inquiry 66(4):486-495. 
Pirazzoli-t'Serstevens, Michele

1992 Cowry and Chinese copper cash as prestige goods in Dian, in Southeast Asian Archaeology 1990: Proceedings of the Third Conference of the European Association of Southeast Asian Archaeologists: 45-52, ed. Ian Glover. Hull, GB: University of Hull, Centre for South-East Asian Studies.

Plourde, Aimée M.

2006 Prestige Goods and their Role in the Evolution of Ranked Societies: A Costly Signaling Model with Data from the Formative Period of the Northern Lake Titicaca Basin, Peru. Ph.D. diss. University of California Los Angeles.

2008 The origins of prestige goods as honest signals of skill and knowledge. Human Nature 19(4):374-388.

2009 Prestige goods and the formation of political hierarchy: A costly signaling model, in Pattern and Process in Cultural Evolution: 265-276, ed. Stephen Shennan. Berkeley: University of California Press.

Renfrew, Colin

1986 Varna and the emergence of wealth in Europe, in The Social Life of Things: Commodities in a Cultural Perspective: 141-168, ed. Arjun Appadurai. Cambridge: Cambridge University Press.

2012 Systems of value among material things: The nexus of fungibility and measure, in The Construction of Value in the Ancient World: 249-260, ed. John K. Papadopoulos and Gary Urton. Los Angeles: Cotsen Institute of Archaeology, University of California at Los Angeles.

Richerson, Peter J., and Robert Boyd

2001 Built for speed, not for comfort: Darwinian theory and human culture. History and Philosophy of the Life Sciences 23(3-4):425-465.

Salomon, Richard G.

1996 Brahmi and Kharosthi, in The World's Writing Systems: 373-383, ed. Peter T. Daniels and William Bright. New York: Oxford University Press.

Saxe, Arthur Alan

1970 Social Dimensions of Mortuary Practices. Ph.D. diss. University of Michigan.

Schmidt-Colinet, Andreas, Annemarie Stauffer, and Khaled Al As'ad

2000 Die Textilien aus Palmyra: Neue und alte Funde [The Textiles from Palmyra: New and Old Finds]. Damaszener Forschungen 8. Mainz am Rhein: Verlag Philipp von Zabern.

Selbitschka, Armin

2010 Prestigegüter entlang der Seidenstraße? Archäologische und historische Untersuchungen zu Chinas Beziehungen zu Kulturen des Tarimbeckens vom zweiten bis frühen fünften Jahrhundert nach Christus [Prestige Goods Along the Silk Road? Archaeological and Historical Analyses of Chinese Relations with Tarim Basin Cultures during the $2^{\text {nd }}$ through $5^{\text {th }}$ Centuries CE]. Asiatische Forschungen 154. Wiesbaden: Harrassowitz.

2015 Early Chinese diplomacy: Realpolitik vs. the so-called tributary system. Asia Major, Third Series 28(1):61-114.

SHANGLUO DiQu WenguANHUi 商洛地區文管會

1997 Shangluo shi Bei Zhou, Sui dai muzang qingli jianbao 商洛市北周隋代墓葬清理簡報 [Preliminary report on the clearing of Northern Zhou and Sui period tombs at Shangluo]. Kaogu yu wenwu 考古與文物 4:3-7.

SHENG, ANGELA

2013 Determining the value of textiles in the Tang Dynasty: In memory of Professor Denis Twitchett (1925-2006). Journal of the Royal Asiatic Society 23(2):175-195.

SHENNAN, STEPHEN

1982a Exchange and ranking: The role of amber in the earlier bronze age of Europe, in Ranking, Resource and Exchange: Aspects of the Archaeology of Early European Society: 33-45, ed. Colin Renfrew and Stephen Shennan. Cambridge: Cambridge University Press.

$1982 b$ Ideology, change and the European early Bronze Age, in Symbolic and Structural Archaeology: 155-161, ed. Ian Hodder. Cambridge: Cambridge University Press.

2002 Genes, Memes and Human History: Darwinian Archaeology and Cultural Evolution. London: Thames and Hudson.

2008 Evolution in archaeology. Annual Review of Anthropology 37:75-91. 
Shijiazhuang Diqu Geweinui Wenhuaju Wenwu Fajuezu 石家庄地區革委會文化局文物發掘組

1977 Hebei Zanhuang Dong Wei Li Xizong mu 河北贊皇東魏李希宗墓 [The Eastern Wei period tomb of Li Xizong in Zanhuang (county), Hebei province]. Kaogu 考古 1977(6):382-391 and 372 .

SKaFF, Jonathan Karam

1998 Sasanian and Arab-Sasanian silver coins from Turfan: Their relationship to international trade and the local economy. Asia Major, Third Series 11(2):67-115.

2003 The Sogdian trade diaspora in East Turkestan during the $7^{\text {th }}$ and $8^{\text {th }}$ century. Journal of the Economic and Social History of the Orient. 46(4):475-534.

StAHL, ANN Brower

2010 Material histories, in The Oxford Handbook of Material Culture: 150-172, ed. Dan Hicks and Mary C. Beaudry. Oxford: Oxford University Press.

Stauffer, Annemarie

1996 Textiles from Palmyra: Local production and the import and imitation of Chinese silk weavings. Palmyra and the Silk Road 42:425-430.

Stein, Aurel

1928 a Innermost Asia: Detailed Report of Explorations in Central Asia, Kan-su and Eastern Iran. Vol. I: Text. Oxford: Clarendon Press.

1928 Innermost Asia: Detailed Report of Explorations in Central Asia, Kan-su and Eastern Iran. Vol. II: Text. Oxford: Clarendon Press.

SWANN, NANCY LEE

1950 Food and Money in Ancient China: The Earliest Economic History of China to A.D. 25. Han shu 24 with related Texts, Han shu 91 and Shi-chi 129. Princeton: Princeton University Press.

SyLWAN, Vivi

1949 Investigation of Silk from Edsen-gol and Lop-nor and A Survey of Wool and Vegetable Materials. Reports from the Scientific Expedition to the North-Western Provinces of China under the Leadership of Dr. Sven Hedin: The Sino-Swedish Expedition Publication, vol. 32, part 7: Archaeology 6. Stockholm: Bokförlags Aktiebolaget Thule.

TAIYUAN SHI WENWU KaOgu YanjIUSUO 太原市文物考古研究所

2010 Shanxi Taiyuan Jinyuan zhen sanzuo Tang bihua mu 山西太原晋源镇三座唐壁画墓 [Three Tang period tombs with wall paintings (excavated) at Jinyuan hamlet near Taiyuan in Shanxi province]. Wenwu 文物 7:33-45.

Tennie, Claudio, Josep Call, and Michael Tomasello

2006 Push or pull: Imitation vs. emulation in great apes and human children. Ethology 112:1159-1169.

Thierry, François, and Cécile Morrisson

1994 Sur les monnaies byzantines trouvées en Chine [On finds of Byzantine coins in China]. Revue numismatique [Journal of Numismatics] series 6(36):109-145.

Trigg, Andrew B.

2001 Veblen, Bourdieu, and conspicuous consumption. Journal of Economic Issues 35(1):99-115.

Trubitt, Mary Beth D.

2000 Mound building and prestige goods exchange: Changing strategies in the Cahokia chiefdom. American Antiquity 65(4):669-690.

TUlufan DiQu WENWUJu 吐魯番地區文物局

$2006 a$ Xinjiang Tulufan diqu Jiaohe gucheng Gouxi mudi Kang shi jiazu mu 新疆吐魯番地區交河 故城溝西墓地康氏家族墓 [Tombs of the Kang family at Gouxi cemetery at the ancient city of Jiaohe in the Tulufan area, Xinjiang]. Kaogu 考古 12:12-26.

$2006 b$ Xinjiang Tulufan diqu 新疆吐鲁番地區木纳爾墓地的發掘 [Excavation of the Muna'er cemetery in the Tulufan area, Xinjiang]. Kaogu 考古 12:27-47.

2006c Xinjiang Tulufan diqu Badamu mudi fajue jianbao 新疆吐鲁番地區巴達木墓地發掘簡報 [Preliminary report on the excavation of Badamu cemetery in the Tulufan area, Xinjiang]. Kaogu 考古 12:47-72.

Underhill, Anne P.

2002 Craft Production and Social Change in Northern China. New York: Kluwer Academic and Plenum Publishers. 
VEBLEn, ThORSTEIN

1899 (1934) The Theory of the Leisure Class: An Economic Study of Institutions. New York: Modern Library.

VON Falkenhausen, Lothar

1999 Inconsequential incomprehensions: Some instances of Chinese writing in alien contexts. Res: Anthropology and Aesthetics 35: 42-69.

2000 Die Seiden mit chinesischen Inschriften [Silks featuring Chinese inscriptions], in Die Textilien aus Palmyra: Neue und alte Funde [The Textiles from Palmyra: New and Old Finds]: 58-81, ed. Andreas Schmidt-Colinet, Annemarie Stauffer, and Khaled Al As'ad. Mainz am Rhein: Verlag Philipp von Zabern.

Wang Binghua 王炳華, LÜ ENGUO 呂恩國, Yu Zhiyong 於志勇, RuAN QiURong 阮秋榮, AND WANG ZONGLEI 王宗否

1999 95MN1 hao mudi de diaocha 95MN1 號墓地的調查 [Investigation of cemetery 95MN1], in Zhong-Ri Ri-Zhong gongtong Niya yiji xueshu diaocha baogaoshu 中日日中共同尼雅遺址學術 調查報告書. Di er quan 第二卷: Benwen bian 本文編 [Report on the scientific SinoJapanese joint investigation of the ruins of Niya. Vol. 2: Text]: 88-132. Wulumuqi 烏魯木齊: Zhong-Ri Ri-Zhong Gongtong Niya Yiji Xueshu Kaochadui 中日日中共同尼雅遺跡學術 考察隊.

WANG, HELEN

2004 How much for a camel? A new understanding of money on the Silk Road before AD 800, in The Silk Road: Trade, Travel, War and Faith: 24-33, ed. Susan Whitfield. Chicago: Serindia Publications.

WANG MingFENG 王明芳

2005 3-5 shiji Zhagunluke de zhijin he cixiu 3-5世紀札滾魯克的織錦和刺繡 [Third through fifth century compound tabby weaves and embroideries from Zhagunluke]. Tulufanxue yanjiu 吐魯 番學研究 2:100-108.

XIA NAI 夏鼎

1959 Xianyang Dizhangwan Sui mu chutu de Dong Luoma jinbi 咸陽底張灣隋墓出土的東羅馬 金幣 [An Eastern Roman gold coin excavated at Dizhangwan in Xianyan]. Kaogu xuebao 考古 學報 3:67-74.

1961 Xi'an Tumencun Tang mu chutude Baizhanting shi jinbi 西安土門村唐墓出土的拜占廷式 金幣 [A Byzantine-style gold coin excavated from a Tang period tomb at Tumencun in Xi'an]. Kaogu 考古 8:446-447.

XI’AN SHI Wenwu BAOHU KaOgusuO 西安市文物保護考古所

2005 Xi'an Bei Zhou Liangzhou sabao Shi Jun mu fajue jianbao 西安北周涼州薩保史君墓發掘簡 報 [Preliminary excavation report on the Western Zhou period tomb of Shi Jun, sabao of Liangzhou]. Wenwu 文物 3:4-33.

XINJIANG BOWUGUAN KAOGUDUI 新疆博物館考古隊

1978 Tulufan Halahuozhuo gumuqun fajue jianbao 吐鲁番哈喇和卓古墓群發掘簡報 [Preliminary excavation report on an ancient cemetery at Halahuozhuo near Tulufan]. Wenwu 文物 1978(6):1-9.

XINJIANG LOULAN KAOGUDUI 新疆樓蘭考古隊

1988 Loulan chengjiao gu muqun fajue jianbao 樓蘭城郊古墓群發掘簡報 [Preliminary report on the excavation of a cemetery in the outskirt of Loulan]. Wenwu 文物 1988(7):23-39.

XINJIANG WeIWU'ER ZiZHIQU BOWUGUAN 新疆維吾爾自治區博物館

1972 Tulufan xian Asitana - Halahuozhuo gumuqun qingli jianbao 吐鲁番阿斯塔那 - 哈喇和卓 古墓群清理簡報 [Preliminary report on the clearing of the ancient cemetery at AsitanaHalahuozhuo in Tulufan county]. Wenwu 文物 1:8-21.

2016 Zhagunluke fangzhipin zhenbao 札滾魯克紡織品珍寶 [Textile treasures of Zaghunluq]. Beijing 北京: Wenwu chubanshe 文物出版社; Riggisberg: Abegg-Stiftung.

Xinjiang Weiwu'er Zizhiqu Bowuguan 新疆維吾爾自治區博物館, Bayinguoleng MengGu ZizhizHOU WENWU GuANLisuo 巴音郭楞蒙古自治州文物管理所, AND QIEMO XIAN WENWU GUANLISUO 且末縣文物管理所

2003a Xinjiang Qiemo Zhagunluke yihao mudi fajue baogao 新疆且末紮滾魯克一號墓地發掘 報告 [Excavation report on Cemetery No. 1 at Zhangunluke in Qiemo (County), Xinjiang]. Kaogu xuebao 考古學報 2003(1):89-136. 
2003 Xinjiang Qiemo Zhagunluke yihao mudi fajue baogao 新疆且末紮滾魯克一號墓地發掘 報告 [Excavation report on Cemetery No. 1 at Zhangunluke in Qiemo (County), Xinjiang]. Xinjiang wenwu 新疆文物 2003(1):1-19.

XINJIANG WENWU KAOGU YANJIUSUO 新疆文物考古研究所

1994 Xinjiang Yuli xian Yinban gumu diaocha 新疆尉犁縣因半古墓調查 [Investigation of Yinban (Yingpan) cemetery in Yuli County, Xinjiang]. Wenwu 文物 1994(10):19-30.

199895 nian Minfeng Niya yizhi 1 hao mudi chuanguan mu fajue jianbao 95 年民豐尼雅遺址 1 號 墓地船棺墓發掘簡報 [Preliminary report on the excavation of a trunk coffin in Tomb No. 1 at cemetery 95[MN1] at the Niya settlement site]. Xinjiang wenuu 新疆文物 1998(2):21-34.

1999a Xinjiang Yuli xian Yingpan mudi 15 hao mu fajue jianbao 新疆尉犁縣營盤墓地 15 號墓發 掘簡報 [Preliminary report on Tomb No. 15 at Yingpan cemetery in Yuli County, Xinjiang]. Wenwu 文物 1999(1):4-16.

$1999 b$ Niya 95 yihao mudi 3 hao mu fajue baogao 尼雅 95 一號墓地 3 號墓發掘報告 [Excavation report on Tomb No. 3 at Niya cemetery 95(MN1)]. Xinjiang wenwu 新疆文物 1999(2):21-26.

1999c Niya 95 mudi 4 hao mu fajue jianbao 尼雅 95 墓地 4 號墓發掘簡報 [Preliminary report on the excavation of Tomb No. 4 at Niya cemetery 95(MN1)]. Xinjiang wenwu 新疆文物 1999 (2):27-32.

2000 Xinjiang Minfeng xian Niya yizhi 95MN1 hao mudi M8 fajue jianbao 新疆民豐縣尼雅遺址 $95 \mathrm{MN} 1$ 號墓地 M8 發掘簡報 [Preliminary report on the excavation of Tomb No. 8 at cemetery 95MN1 at the Niya settlement site in Minfeng County, Xinjiang]. Wenwu 文物 2000 (1):4-40.

2001 Xinjiang Yuli Yingpan mudi 1995 nian fajue baogao 新疆尉犁縣營盤墓地 1995 年發掘簡 報 [Preliminary report of the 1995 campaign at Yingpan cemetery in Yuli County, Xinjiang]. Xinjiang wenwu 新疆文物 2001(1-2):3-46.

$2002 a$ Xinjiang Yuli xian Yingpan mudi 1999 nian fajue jianbao 新疆尉犁縣營盤墓地 1999 年發掘 簡報 [Preliminary report of the 1999 campaign at Yingpan cemetery in Yuli County, Xinjiang]. Kaogu 考古 2002(6):58-74.

$2002 b$ Xinjiang Yuli xian Yingpan mudi 1995 nian fajue jianbao 新疆尉犁縣營盤墓地 1995 年發掘 簡報 [Preliminary report of the 1995 campaign at Yingpan cemetery in Yuli County, Xinjiang]. Wenwu 文物 2002(6):4-45.

YU LiZI 羽离子

2006 Dui Zhongguo xibei diqu xin chutu sanmei Dong Luoma jinbi de kaoshi 對中國西北地區新 出土三枚東羅馬金幣的考釋. [A study of three newly discovered Eastern Roman gold coins from northwestern China]. Kaogu 考古 2006(2):73-80.

YÜ, YING-SHIH

1967 Trade and Expansion in Han China: A Study in the Structure of Sino-Barbarian Economic Relations. Berkeley: University of California Press.

YuANZHOU LianHe KaOGUdUI 原州聯合考古隊

2009 Bei Zhou Tian Hong mu 北周田弘墓 [The Northern Zhou period tomb of Tian Hong]. Beijing 北京: Wenwu chubanshe 文物出版社.

2014 Tang Shi Daoluo mu 唐史道洛墓 [The Tang period tomb of Shi Daoluo]. Beijing 北京: Wenwu chubanshe 文物出版社.

ZAHAVI, АмотZ

1995 Altruism as a handicap: The limitations of kin selection and reciprocity. Journal of Avian Biology 26(1):1-3.

Zahavi, Amotz, and Avishag Zahavi

1997 The Handicap Principle: A Missing Piece of Darwin's Puzzle. Oxford and New York: Oxford University Press.

Zhang Haiyun 張海雲, LiaO CAILIANG 廖彩梁, AND Zhang Minghui 張銘惠

1986 Xi'an shi xijiao Caojiabao Tang mu qingli jianbao 西安西郊曹家堡唐墓清理簡報 [Preliminary report on the clearing of a Tang period tomb at Caojiabao in the western suburbs of Xi'an]. Kaogu yu wenwu 考古與文物 1986(2):22-26.

ZHANG QuANMIN 張全民, AND WANG ZiLI 王自力

1992 Xi'an dongjiao qingli de liangzuo Tang mu 西安東郊清理的兩座唐墓 [Clearing of two Tang period tombs in the eastern suburbs of Xi'an]. Kaogu yu wenwu 考古與文物 1992 (5):51-57.

ZHAO FENG 趙豐

2002 Fangzhipin kaogu xin faxian 紡織品考古新發現 [Recent excavations of textiles in China]. Hangzhou 杭州: Zhongguo sichou bowuguan 中國絲綢博物館. 
2005a Zhongguo sichou yishu shi 中國絲綢藝術史 [History of Chinese textile art]. Beijing 北京: Wenwu chubanshe 文物出版社.

2005b Zhongguo sichou tongshi 中國絲綢通史 [Comprehensive history of Chinese silk]. Suzhou 蘇州: Suzhou daxue chubanshe 蘇州大學文物出版社.

ZHAO FeNG 趙豐 AND Yu ZHIYONG 於志勇

2000 Shamo wangzi yibao zhan: Sichou zhi lu Niya yizhi chutu wenwu 沙漠王子遺寶展: 絲綢之路尼 雅遺址出主文物 [Legacy of the desert king: Textiles and treasures excavated on the Silk Road]. Hangzhou 杭州: Zhongguo sichou bowuguan 中國絲網博物館.

Zhongguo Shehui KeXueyuan Kaogu Yanjiusuo 中國社會科學院考古研究所 ANd Xinjiang BAYINGUOLENG MENGgu ZiZHiZHOU WenguANSUO 新疆巴音郭楞蒙古自治州文管所

1997 Xinjiang Qiemo xian Jiawa'airike mudi de fajue 新疆且末縣加瓦艾日克墓地的發掘 [Excavation of the cemetery at Jiawa'airike in Qiemo County, Xinjiang]. Kaogu 考古 1997(9):21-32. 